\title{
LICENSE TO BLOG: INTERNET REGULATION IN THE PEOPLE'S REPUBLIC OF CHINA
}

\author{
Trina K. Kissel*
}

\section{INTRODUCTION}

In 1998 , a study boldly predicted that by 2005 , the number of Internet users in China would grow "exponentially" to reach 16 million. ${ }^{1}$ The study grossly underestimated the figure: by the end of 2005 the actual number of Internet users in China reached 111 million. ${ }^{2} \mathrm{~A}$ few years ago, there were only "a handful" of weblogs (blogs) in China, ${ }^{3}$ but by the end of 2005 , the number of blogs had skyrocketed to 36.82 million. ${ }^{4}$ Worldwide, one blog is created every second. ${ }^{5}$ These statistics demonstrate both the rapidity with which people adopt new uses of technology and also portend the difficulties a government might encounter in regulating emerging technology.

\footnotetext{
* J.D. candidate 2007. The author would like to thank Professor Kenneth Crews for his assistance.

1. Kristina M. Reed, Comment, From the Great Firewall of China to the Berlin Firewall: The Cost of Content Regulation on Internet Commerce, 13 TRANSNAT'L LAW. 451, 460 (2000) (citing China: A Shift in Focus with a Little Restructuring, ASIA-PAC. TELECOMM.,
} Oct. 1, 1998).

2. Embassy of the People's Republic of China in the United States of America, China Has 111 Million Internet Users, (Jan. 18, 2006), http://www.chinaembassy.org/eng/xw/t231597.htm [hereinafter 111 Million]. The only country to surpass China in Internet usage is the United States, with an online population of about 135 million. Audra Ang, China Wants Web News 'Civilized', Deseret Morning News, Sept. 26, 2005, at A4, available at 2005 WLNR 15133888 . This represents $67 \%$ of the total U.S. population. China Daily, Internet Users Reach 103 Million: Survey, (July 22, 2005), http://www.china.org.cn/english/BAT/135701.htm. In contrast, China's online population represents about $8.5 \%$ of its total population. 111 Million, supra. Within six months, China's internet population had vastly expanded again to 123 million. Sumner Lemon, China's Internet Population Hits 123 Million, http://www.infoworld.com/article/06/07/19/HNchinainternet_1.html (last visited Dec. 18, 2006).

3. Mat Honan, Little Red Blogs, salon.com, June 4, 2004, http://dir.salon.com/story/tech/feature/2004/06/04/china_blogs/index.html. A weblog is defined as "a personal Web site that provides updated headlines and news articles of other sites that are of interest to the user, [which] also may include journal entries, commentaries and recommendations." Dictionary.com, Weblog, http://dictionary.reference.com/search?q=blog (last visited Dec. 18, 2006). Authoring a blog, or "blogging," has occurred since about 1994 , although the term "weblog" was not coined until 1997. See Clive Thompson, The Early Years: A Timeline of the History of Blogging, N.Y. MAG., Feb. 20, 2006, available at http://nymag.com/news/media/15971.

4. People's Daily Online, MSN Spaces Rated the Leading Blog Service Provider in China, (Dec. 20 , 2005), http://english.peopledaily.com.cn/200512/20/eng20051220_229546.html.

5. BBC News, One Blog Created 'Every Second,' (Aug. 2, 2005), http://news.bbc.co.uk/1/hi/technology/4737671.stm. 
Since the development of the Internet, China's government has welcomed technological advances because of the increased opportunity for economic development and the potential for China to become a global leader in ecommerce. $^{6}$ However, Internet access creates important social ramifications with which the Chinese Communist Party (CCP or Party) must contend because the development of the Internet in China occurs in a single-party, communistcontrolled country. "The political solidarity of China's [one-party system] depends heavily upon maintaining ideological unanimity, and this, in turn, necessitates close State control of all information flows."8 Though the CCP wants to utilize the Internet for economic development, the government is also concerned with the citizens' ability to access information that may be antithetical to Party objectives. ${ }^{9}$

The year 2005 completed the first decade of publicly available Internet access in China. ${ }^{10}$ The CCP created many regulations during this decade and imposed control of the Internet through a variety of methods. These stringent mechanisms of control have caused China's Internet to be dubbed the "Great Firewall."11 After the first regulations were imposed in 1996, subsequent regulations were adopted either to strengthen or clarify previous regulations ${ }^{12}$ or to deal with an unforeseen problem caused by emerging technology. ${ }^{13}$

Two regulations promulgated in 2005, the Registration Administration Measures for Non-Commercial Internet Information Services (Registration Measures) and the Rules on the Administration of Internet News Information Services (Administration of News), typify the reasons the CCP creates new Internet regulations. These rules strengthen existing Internet laws and add new provisions for emerging uses of technology, which is accomplished through registration requirements for all non-commercial websites and stringent regulation of the posting of news-related content, including political commentary. ${ }^{14}$ Media outside of China characterized both regulations as being

6. Fuping Gao, The E-Commerce Legal Environment in China: Status Quo and Issues, 18 TEMP. INT'L \& COMP. L.J. 51, 52 (2004).

7. Richard Cullen \& D.W. Choy, China's Media: The Impact of the Internet, 6 SAN DIEGo INT'L L.J. 323, 326 (2005). See also Lawrence B. Solum \& Minn Chung, The Layers Principle: Internet Architecture and the Law, 79 NOTRE DAME L. REV. 815, 895 (2004).

8. Cullen \& Choy, supra note 7 , at 326.

9. Reed, supra note 1, at 459-60. See also Cullen \& Choy, supra note 7, at 327.

10. Clara Liang, Note, Red Light, Green Light: Has China Achieved Its Goals Through the 2000 Internet Regulations?, 34 VAND. J. TRANSNAT'L L. 1417, 1422 (2001).

11. Traci E. Carpenter, 'Great Firewall' How China Is Using American Technology to Censor the Internet-and Why This Hurts U.S. Interests, NEWSWEEK, July 21, 2005, http://www.msnbc.msn.com/id/ 8662273/site/newsweek/.

12. Cullen \& Choy, supra note 7 , at 329.

13. Fourteen Departments United to "Purify" the Internet, NANFANG WEEKEND, Aug. 18, 2005, translated in EastSouthWestNorth, Purifying the Chinese Internet, http://www.zonaeuropa.com/20050821_1.htm (last visited Dec. 18, 2006) [hereinafter Fourteen Departments].

14. See Congressional-Executive Commission on China, Ministry of Information Industry: Web Sites that Fail to Register May Be Shut Down, 
adopted in response to the rapidly growing popularity of blogging in China. ${ }^{15}$

This Note will discuss the CCP's legal and technological responses to the rapidly growing availability of Internet access and examine some of the reasons that the CCP finds strict control necessary. Part A of this Note will look at recent Internet regulations, such as the Registration Measures and the Administration of News, in the context of the three methods that the CCP uses for Internet control. The first method imposes civil and criminal liability through Internet content regulation. The second method employs technological mechanisms to restrict website content and enforce the legal regulations. The third method restricts citizens' ability to access the Internet through personal registration requirements and strict regulation of Internet cafes.

Part B will discuss the unique characteristics of the Internet that cause the $\mathrm{CCP}$ to regulate the Internet in these three ways. The unique characteristics of the Internet that necessitate strict regulation include the anonymous character of posting and accessing information on the Internet, the ability for all citizens to freely exchange ideas and information, the rapidly changing technology that makes control more difficult, the ability for sophisticated users to bypass technological control, and efforts by Western parties to end Internet censorship in China.

\section{A. METHODS OF REGULATION}

Historically, the CCP used the press as a platform for propaganda, utilizing it as a method of "disseminating its goals and values."16 The Party traditionally controlled the media through "direct government regulation, censorship, and strict enforcement." 17 As technology has advanced, the CCP has reacted with suspicion and created methods to control new developments in technology. ${ }^{18}$ The reasons for the Party's suspicion of technology are undoubtedly complex and cannot be traced to one particular factor or historical event; however, certain occurrences, such as the Tiananmen Square tragedy, likely play a role in causing the Party to distrust emerging technology. ${ }^{19}$

In 1989, at Tiananmen Square, student protesters gathered to urge for democracy in China. ${ }^{20}$ The military killed and wounded an unknown number

http://cecc.gov/pages/virtualAcad/index.phpd?showsingle=13937 (last visited Dec. 18, 2006) [hereinafter MII]; Congressional-Executive Commission on China, Government Agencies Issue New Regulations Restricting News Reporting on the Internet, http://www.cecc.gov/pages/virtualAcad/index.phpd?showsingle=25176 (last visited Oct. 4, 2006) [hereinafter Government Agencies].

15. Charles Hadlock, China Toughens Restrictions on Internet News, (Sept. 26, 2005), http://www.msnbc.msn.com/id/9489510/.

16. Reed, supra note 1 , at 460 .

17. Liang, supra note 10 , at 1426 .

18. Jill R. Newbold, Note, Aiding the Enemy: Imposing Liability on U.S. Corporations for Selling China Internet Tools to Restrict Human Rights, 2003 U. IL. J.L. TECH. \& POL'Y 503, 507 (2003).

19. Id.

20. Id. 
of protestors; estimates range from a few hundred killed to seven thousand killed and as many as thirty thousand wounded. ${ }^{21}$ Political protestors used fax machines, which were "cutting edge technology at the time," to release information of the massacre to the outside world.2

After Tiananmen Square, the Party eliminated almost thirteen percent of news publications to reduce apparent threats to its authority. ${ }^{23}$ The CCP also recognized the role that emerging communications technology played in the incident, and thus "views the Internet, a tool far more powerful than [fax] machines, with a correspondingly greater suspicion."24 From the CCP's perspective, strict Internet regulation is necessary because certain websites contain material such as "unhealthy news stories that will easily mislead the public," 25 information content that is considered "feudalistic and superstitious ... [which] poison[s] people's spirits," ${ }^{26}$ or political commentary that will create "ideological confusion," especially among college students. ${ }^{27}$ Thus, the $\mathrm{CCP}$ has strictly regulated the Internet since its inception. ${ }^{28}$

Although the CCP attempts to curtail citizens' access to political dissent, it has also found the Internet useful in positively reinforcing Party messages. ${ }^{29}$ Government websites are used to publicize information about the CCP's "stance on various controversial issues" and as "a platform to advance its political agenda." 30 The government also employs citizens to anonymously "offer opinions and write blogs in support of the government, either from a nationalistic perspective or in other ways." to the Party goes beyond the employment of a few individuals; "[n]ational security and propaganda departments [have] . . trained a network of on-line 'commentators' to manipulate public opinion as expressed in Internet forums, [Bulletin Board Systems], and message groups." 32

Despite the ability to emphasize positive Party information through the

21. Id. See also Wikipedia.org, Tiananmen Square Protests of 1989, http://en.wikipedia.org/wiki/tiananmen_square_protests_of_1989 (last visited Dec. 18, 2006).

22. Newbold, supra note 18 , at 507.

23. Liang, supra note 10 , at 1426 .

24. Newbold, supra note 18, at 507.

25. Government Agencies, supra note 14.

26. MII, supra note 14 .

27. Congressional-Executive Commission on China, Two Provinces Force Universities to Implement "Real Name Systems" for Internet Forums, http://www.cecc.gov/pages/virtualAcad/index.phpd?showsingle=25569 (last visited Oct. 4, 2006). (2004).

28. Charles Li, Internet Content Control in China, 8 INT'L J. CoMM. L. \& PoL'y 1, 6

29. Cullen \& Choy, supra note 7, at 328.

30. Id. at 328-29.

31. Chris Gill \& David Stanway, Cloak and Daggers in Cyberspace-Dark Tales from China's Internet, CHINA Bus. NEws ON-LINE, Oct. 13, 2005, at 1.

32. Radio Free Asia, China Tightens Grip on Cyberspace, (Aug. 17, 2005), http://www.rfa.org/english/news/in_depth/2005/08/17/internet_china/ [hereinafter China Tightens Grip]. 
Internet, the CCP has exerted far more effort in attempting to shield its citizens from information that portrays the Party in a negative light. ${ }^{33}$ The CCP does this through a variety of mechanisms. ${ }^{34}$ Many Internet regulations impose criminal and civil liability "down the food chain" upon Internet Service Providers (ISPs), Internet Content Providers (ICPs), and citizens who access the Internet. ${ }^{35}$ The Party also uses multi-faceted technological controls to prevent access to forbidden information. ${ }^{36}$ Finally, the CCP has made it more difficult for citizens to access the Internet, requiring citizens to register for Internet access by providing personal identification information and closely monitoring the Internet cafes that many citizens use to access the Internet. ${ }^{37}$

\section{Legal Control}

The CCP has regulated the Internet extensively, dating back to $1996{ }^{38}$ The regulations cover many aspects of Internet governance, such as infrastructure, ${ }^{39}$ e-commerce, ${ }^{40}$ intellectual property, ${ }^{41}$ security, ${ }^{42}$ content restriction, ${ }^{43}$ and duties imposed upon individual citizens, ISPs, and ICPs. ${ }^{44}$ The Party first created Internet regulations to control the physical connection to the Internet. ${ }^{45}$ Since then, the focus of the regulations has shifted primarily, though not exclusively, to content control. ${ }^{46}$ More than sixty regulations govern the type of content that is permitted or forbidden on the Internet. ${ }^{47}$ In addition, the regulations are enforced by local, provincial, and national government bodies whose jurisdictions may overlap; ${ }^{48}$ at least twelve government divisions

33. Congressional-Executive Commission on China, 2005 Annual Report, at III(e), http://www.cecc.gov/pages/annualRpt/annualRpt05/2005_3e_expression.php (last visited Sept. 24, 2006) [hereinafter 2005 Annual Report].

34. See generally Reporters Without Borders, Living Dangerously on the Net: Censorship and Surveillance of Internet Forums, May 12, 2003, http://www.rsf.org/article.php3?id_article=6793 (describing methods of control over information posted on websites) [hereinafter Living Dangerously].

35. Cullen \& Choy, supra note 7, at 329.

36. See generally OPENNET INITIATIVE, INTERNET FILTERING IN CHINA IN 2004-2005: A COUNTRY STUDY, http://www.opennetinitiative.net/studies/china/ONI_China_Country_Study.pdf (describing various methods of technological control) [hereinafter ONI].

37. See Reed, supra note 1, at 462; Ang, supra note 2.

38. Newbold, supra note 18 , at 507-08.

39. $\mathrm{Li}$, supra note 28 , at 6 .

40. Gao, supra note 6 , at 60 .

41. Alicia Beverly, Protecting Your IP in China, ManUfaCtURER's MonThLy (AUSTL.), Sept. 2006.

42. Li, supra note 28 , at 6 .

43. Newbold, supra note 18 , at 508 .

44. Cullen \& Choy, supra note 7, at 329.

45. $\mathrm{Li}$, supra note 28 , at 6 .

46. Id.

47. Id.

48. Cullen \& Choy, supra note 7 , at 327. 
regulate different aspects of the Internet. ${ }^{49}$ Businesses and individuals find that adherence to the regulations is difficult because the rules are often "vague, confusing, and inconsistent." ${ }^{.50}$

A brief overview of some of the significant content regulation demonstrates how the Party's tactics have evolved over time by changing who is liable for illegal content, ${ }^{51}$ who is responsible for maintaining control over content, ${ }^{52}$ and what type of content is illegal..$^{53}$ On February 1, 1996, the State Council promulgated the Interim Provisions Governing Management of Computer Information Networks (Interim Provisions). ${ }^{54}$ This was the first strategic effort by the Party to control the Internet. ${ }^{55}$

Article Thirteen of the Interim Provisions provided that "[n]o unit or individual may use the Internet to engage in criminal activities such as harming national security or disclosing state secrets. No unit or individual may use the Internet to retrieve, replicate, create, or transmit information that threatens social stability and promotes sexually suggestive material." 56 The Interim Provisions placed liability upon individuals who post and access content on the Internet. ${ }^{57}$ Organizations and citizens were compelled to register with the Ministry of Public Security (MPS) in order to access the Internet. ${ }^{58}$ The

49. ONI, supra note 36 , at 54. The departments that regulate some aspect of the Internet include: Central Propaganda Department; Department of Commerce; Department of Telecommunications; General Administration of Press and Publications; Ministry of Culture; Ministry of Information Industry; Ministry of Public Security; Public Security Bureau; State Administration of Radio, Film, and Television State Council; State Council Information Agency; and State Secrets Bureau. Id.

50. Li, supra note 28 , at 5 .

51. See, e.g., Measures for the Administration of Internet Information Services, (promulgated by the State Council, Sept. 20, 2000), art. 14, translated in China ePulse, Measures for the Administration of Internet Information Services, http://www.chinaepulse.com/html/regulation.html (last visited Dec. 18, 2006) [hereinafter 2000 Measures].

52. Li, supra note 28 , at 6 .

53. See, e.g., 2000 Measures, supra note 51, art. 15.

54. Newbold, supra note 18 , at 507. The State Council is the "highest authority of state administration with the power to enact nationwide law." Id. "It is comprised of the General Affairs Office and twenty-eight ministries and commissions." China.org.cn, The Organizational Structure of the State Council, http://www.china.org.cn/english/kuaixun/64784.htm (last visited Dec. 18, 2006) [hereinafter Organizational Structure]. It includes the Ministry of Public Security, see infra, note 58, and the Ministry of Information Industry, see infra, note 92.

55. Newbold, supra note 18 , at 508 .

56. Id.

57. Id.

58. Scott E. Feir, Comment, Regulations Restricting Internet Access: Attempted Repair of Rupture in China's Great Wall Restraining the Free Exchange of Ideas, 6 PAC. RIM L. \& PoL'Y J. 361, 370 (1997). The MPS oversees public security and is the "highest leading and commanding organ of the Armed Police." Organizational Structure, supra note 54. It functions to create guidelines, policies, rules, and regulations for public security, and it oversees the implementation of regulations at local security posts. Id. In addition, it has the authority to "investigate computer crimes, furnish computer security training, and institute computer security regulations." Liang, supra note 10, at 1432. 
mandatory registration required that people appear at the local police station and provide demographic information, ${ }^{59}$ the name of their ISP, their e-mail address, and any newsgroups to which they subscribe. ${ }^{60}$

In 1998, the State Council promulgated the Provisions for the Implementation of the Interim Provisions Governing the Management of Computer Information Networks (Implementation Provisions). ${ }^{61}$ The Implementation Provisions make clear that both individual users and ISPs share liability for illegal content posted on the Internet. ${ }^{62}$ These regulations were the second key effort made to control the Internet. ${ }^{63}$

The next important effort by the CCP to regulate the Internet occurred in September 2000. ${ }^{64}$ The Measures for Managing Internet Information Services (2000 Measures) made several changes in the way the Internet was governed. ${ }^{65}$ The 2000 Measures required ISPs to record the dates and times when subscribers accessed the Internet, the subscriber's account number, the addresses of all websites visited, and the telephone number used to access the Internet. ${ }^{66}$ The ISPs must keep a record of this information for sixty days and provide it to the authorities upon request. ${ }^{67}$

The 2000 Measures also required all commercial websites to acquire a license from the State Council or other local government office in order to legally offer commercial services online. ${ }^{68}$ All licensed commercial websites must display the license number in a prominent place on the home page of the website and must guarantee that the information provided on the site is published in accordance with the law. ${ }^{69}$

The 2000 Measures were the first regulations to impose liability upon ICPs, ISPs, and individuals. ${ }^{70}$ ICPs, ISPs, and individuals are restricted from producing or disseminating nine enumerated categories of information; for example, no information may be posted on the Internet that "instigates ethnic hatred or ethnic discrimination or that undermines national unity." The 2000 Measures also prohibit Internet content that "spreads pornography or other salacious materials, promotes gambling, violence, homicide, or terrorism, or instigates crime."72

The CCP also promulgated the Provisions for the Administration of

59. Feir, supra note 58, at 370.

60. Reed, supra note 1 , at 462 .

61. Newbold, supra note 18, at 508.

62. Id.

63. Id.

64. Cullen \& Choy, supra note 7 , at 329.

65. Id.

66. 2000 Measures, supra note 51 .

67. Id.

68. Id. art. 7.

69. Id. arts. 12-13.

70. See Cullen \& Choy, supra note 7, at 329 .

71. 2000 Measures, supra note 51, art. 15.

72. Id. 
Electronic Bulletin Board System Services (BBS Provisions) in $2000 .^{73}$ The BBS Provisions impose liability upon BBS providers similar to that of ISPs. BBS providers must monitor the information posted on the bulletin board and keep records of the details of users, the content they post, and the time of posting. $^{74}$

Also in 2000, the State Secrets Protection Regulations for Computer Information Systems on the Internet were promulgated (State Secrets Law). ${ }^{75}$ The State Secrets Law makes it a crime to divulge state secrets online. ${ }^{76}$ It also imposes a duty upon ISPs, BBS operators, chat room operators, and news group organizers to create a mechanism to ensure that state secrets are not transmitted using their systems. ${ }^{77}$ The law does not define what a state secret consists of, and it has been described as being "so broad that it can cover almost everything."78 Each information-producing government body has the ability to determine whether a piece of information constitutes a state secret, and the courts have no review over that determination. ${ }^{79}$ A subsequent interpretation of law by the Supreme People's Court, the highest court in China, provides that if a state secret is disclosed online under serious circumstances, the punishment must be in accordance with Article 111 of the Criminal Law. ${ }^{80}$ This law allows for a maximum penalty of death. ${ }^{81}$

Through these increasingly stringent regulations, the CCP has developed a system of law that holds many entities and individuals accountable for accessible content on the Internet. ${ }^{82}$ By placing accountability first upon Internet users, then upon ISPs, and finally upon ICPs, the Party has decentralized regulation by shifting the responsibility for content control away from the government. ${ }^{83}$ This ensures that content on the Internet is "not double- but triple-checked: at the gateway . . . , at the network responsible for delivering the content, and [at] the receiver itself." ${ }^{, 84}$ Creating levels of control

73. Cullen \& Choy, supra note 7 , at 331 .

74. Id.

75. Id. at 331-32.

76. Id. at 332. See also Provisions on the Administration of the Protection of Secrets on Internationally Networked Computer Information Systems (Jan 1. 2000), art. 10, translated in Congressional-Executive Commission on China, PRC Domestic Laws and Regulations: National Security and State Secrets, http://cecc.gov/pages/virtualAcad/exp/explaws.php\#secretsonnetworkslaw (last visited Dec. 18, 2006) [hereinafter State Secrets].

77. Cullen \& Choy, supra note 7, at 332-33. Article 8 of the State Secrets Law declares that the administration of the law must adhere to the principle of "those who go online shall bear responsibility." State Secrets, supra note 76.

78. Cullen \& Choy, supra note 7 , at 332.

79. Id.

80. Id. at 333 .

81. Id.

82. Id. at 329.

83. Li, supra note 28 , at 6 .

84. Id. For a discussion of China's Internet gateways, see infra notes 196-99 and accompanying text. 
in this manner is an effective way "to make Internet participants adhere to those norms beneficial to the [Party's] control." ${ }^{, 85}$

The types of information that constitute illegal content have also evolved. ${ }^{86}$ The 1996 Interim Provisions prohibited four categories of information that would harm national security, disclose state secrets, threaten social stability, or include sexually suggestive materials. ${ }^{87}$ By contrast, the 2000 Measures included nine broad categories of forbidden information. ${ }^{88}$

Two sets of regulations promulgated in 2005 naturally evolved from previous Internet regulation in China. Like the preceding regulations, the new laws identify even broader categories of forbidden information, ${ }^{89}$ create enhanced accountability, ${ }^{90}$ and focus more directly on newer uses of Internet technology like blogging. ${ }^{91}$

\section{a. Registration Administration Measures for Non-Commercial Internet Information Services}

On February 8, 2005, the Ministry of Information Industry (MII) promulgated the Registration Administration Measures for Non-Commercial Internet Information Services. ${ }^{92}$ The Registration Measures require that all noncommercial websites carry out registration procedures with the Communications Administration Office in the province where the individual or organization resides. ${ }^{93}$ Anyone who does not register is prohibited from operating a non-commercial website within China. ${ }^{94}$ Commercial websites

85. Id.

86. For example, compare the Interim Provisions with the 2000 Measures. See Newbold, supra note 18, at 507; 2000 Measures, supra note 51, art. 15.

87. Newbold, supra note 18 , at 507.

88. 2000 Measures, supra note 51 , art. 15.

89. See, e.g., Provisions on the Administration of Internet News Information Services (promulgated by State Council Information Office \& Ministry of Information Industry, Sept. 25, 2005), translated in Congressional-Executive Commission on China, Provisions on the Administration of Internet News Information Services, http://cecc.gov/pages/virtualAcad/index.phpd?showsingle=24396 (last visited Dec. 18, 2006) [hereinafter Administration of News].

90. Government Agencies, supra note 14.

91. Hadlock, supra note 15.

92. MII, supra note 14. The MII is responsible for the "manufacture of electronic and information products, telecommunication industry and the software industry, promotion of information in the national economy and social services in the country...." Organizational Structure, supra note 54.

93. Registration Administration Measures for Non-Commercial Internet Information Services (promulgated by Ministry of Information Industry, Jan. 28, 2005), art. 3, translated in Congressional-Executive Commission on China, Registration Administration Measures for NonCommercial Internet Information Services, http://www.cecc.gov/pages/virtualAcad/index.phpd?showsingle=12212 (last visited Dec. 18, 2006) [hereinafter Registration Measures].

94. Id. art. 5. 
were already subject to licensure by the 2000 Measures. ${ }^{95}$

The MII asked local administrators to complete registration of noncommercial websites by June $30,2005 .^{96}$ Local authorities in several Chinese provinces began to register the non-commercial websites in May $2005 .^{97}$ On July 2, 2005, Chinese agencies temporarily shut down 100,000 websites that had not registered; the agencies permitted some websites that subsequently registered to re-open. ${ }^{98}$ Other websites were refused permission to register because they did not prove they had permission to post certain types of regulated content. ${ }^{99}$ Certain other websites were permanently black-listed and will never be permitted to reopen. ${ }^{100}$ It is estimated that one quarter of all Chinese websites were temporarily closed for failing to register with the CCP. ${ }^{101}$

One example of a website that was temporarily shut down was that of computer chip-maker Intel. ${ }^{102}$ The company had failed to register its Chinese domain name with the authorities, ${ }^{103}$ but after registering the domain name on the next day, the site was restored. ${ }^{104}$ Individual citizens may not be able to register with the same ease. ${ }^{105}$ A blogger found his website inaccessible after his failure to register; he telephoned the MII and was told that it was "not worth bothering" because "there was no chance of an independent blog getting permission to publish." "106 Another website owner expressed that he would not attempt to register his website because it would enable authorities to prosecute him for previously publishing illegal content. ${ }^{107}$

\section{b. Rules on the Administration of Internet News Information Services}

On September 25, 2005, the State Council and the MII promulgated the Administration of News regulations. ${ }^{108}$ The Administration of News defines "News Information" to include "reporting and commentary relating to politics,

95. 2000 Measures, supra note 51 , art. 4 .

96. MII, supra note 14.

97. Id.

98. Congressional-Executive Commission on China, Authorities Begin to Sanction, Permanently Shut Down Web Sites that Failed to Register with the Government, $\mathrm{http} / / / \mathrm{cecc}$.gov/pages/virtualAcad/index.phpd?showsingle=17821 (last visited Dec. 18, 2006).

99. Id.

100. Id.

101. 2005 Annual Report, supra note 33, at III(e) n.44.

102. John Liu, China Closes Unregistered Websites En Masse Before Christmas, CHINA IT \& TeleCOM RePORT, Dec. 26, 2005 [hereinafter Liu, China Closes].

103. Intel, http://www.intel.com.cn (last visited Dec. 18, 2006).

104. Liu, China Closes, supra note 102.

105. Id.

106. Reporters Without Borders, Authorities Declare War on Unregistered Websites and Blogs (June 6, 2005), http://www.rsf.org/article.php3?id_article=14010 [hereinafter Authorities Declare War].

107. Liu, China Closes, supra note 102.

108. Administration of News, supra note 89. 
economics, military affairs, foreign affairs, and social and public affairs, as well as reporting and commentary relating to fast-breaking social events."109

The regulations require the organizations that provide news to perform four functions. ${ }^{110}$ First, they must abide by the Chinese Constitution, laws, and regulations." Second, they must be "oriented toward serving the people and serving socialism." 112 Third, they must "correctly guide public opinion."113 Finally, they must "safeguard the nation's interests and the public interest."114 The Rules also "encourage" news organizations to "disseminate healthy and civilized News Information that is conducive to raising the quality of the nation, promoting economic development, and spurring social progress." 115

The Administration of News enumerates eleven categories of news information that may never be posted online. ${ }^{116}$ The prohibited subjects are worded vaguely and could encompass a wide variety of information that might be used to challenge the CCP's control. ${ }^{117}$ For example, Internet content that would "jeopardize the security of the nation, divulge state secrets, subvert the national regime, or jeopardize the integrity of the nation's unity" is one of the categories of forbidden information. ${ }^{118}$ The eleven categories include the original nine categories of content information that were forbidden by the 2000 Measures and two additional categories. ${ }^{119}$ The first new category of forbidden information includes "inciting illegal assemblies, associations, marches, demonstrations, or gatherings that disturb social order." 120 The second new category includes "conducting activities in the name of an illegal civil organization."121

There are three types of news organizations that may post online news content. $^{122}$ The first type includes news organizations established by a government agency that post news that employees of that agency gathered and reported. ${ }^{123}$ The second type includes news organizations established by government agencies that post news that employees of another government agency gathered and reported. ${ }^{124}$ The third type is one that is established by a

109. Id. art. 2 .

110. Id. art. 3 .

111. Id.

112. Id.

113. Id.

114. Id.

115. Id.

116. Id. art. 19.

117. Human Rights Watch, China: End Censorship of Internet, (Sept. 28, 2005), http://hrw.org/english/docs/2005/09/28/china1 1798_txt.htm [hereinafter End Censorship].

118. Administration of News, supra note 89, art. 19.

119. Compare the 2000 Measures and the Administration of News. 2000 Measures, supra note 51, art. 19; Administration of News, supra note 89, art. 19.

120. Administration of News, supra note 89 , art. 19.

121. Id.

122. Id. art. 5 .

123. Id. See also Government Agencies, supra note 14.

124. Administration of News, supra note 89, art. 5. See also Government Agencies, supra 
non-government entity. ${ }^{125}$

The second and third types of news organizations may not post online information that they have gathered and edited themselves. ${ }^{126}$ The news information reprinted online must reference the source of the information and may not distort the original content. ${ }^{127}$ No organization providing Internet news may be operated by a Chinese-Foreign joint venture, cooperative venture, or a wholly foreign-owned venture. ${ }^{128}$ Chinese-Foreign ventures that work cooperatively are acceptable but must report to the State Council to complete a security evaluation. ${ }^{129}$

Anyone who posts online news information without authorization or, if authorized, exceeds the scope of their authority will be fined between 5000 and 30,000 yuan, depending on the nature of the violation. ${ }^{130}$ If incorrect information is posted online, an organization may be asked to correct or delete it; if the circumstances are severe, access to the online content will be terminated. ${ }^{131}$

Violating the Administration of News regulations could also result in violation of several other laws, subjecting the user to the sanctions imposed by those laws. For example, if a news organization posted information that was considered a state secret in violation of the Administration of News regulations, it is also likely a violation of the State Secrets law. The State Secrets law allows far greater penalties to be imposed, including imprisonment or execution. $^{132}$

The Administration of News implements several significant changes to the manner in which the 2000 Measures regulated Internet sites and activities. $^{133}$ Previous regulations did not impose restrictions on BBS, blogs, news alerts sent by e-mail, or Short-Message Systems (SMS) used to send news alerts via cellular telephones. ${ }^{134}$ The previous regulations did not differentiate between news organizations; the Administration of News establishes the three categories of news providers and restricts the latter two categories from publishing news unless it has already been published by a government news agency. ${ }^{135}$ Finally, the Administration of News sets new restrictions on

note 14.

125. Administration of News, supra note 89, art. 5. See also Govemment Agencies, supra note 14.

126. Administration of News, supra note 89, art. 16. See also Government Agencies, supra note 14.

127. Administration of News, supra note 89 , art. 16.

128. Id. art. 9.

129. Id.

130. Id. art. 26-29. Five thousand yuan is approximately $\$ 620$ (USD), and 30,000 yuan is approximately $\$ 3700$ (USD). Universal Currency Converter, http://www.xe.com/ucc (last visited Dec. 18, 2006).

131. Administration of News, supra note 89, arts. 26-28.

132. Cullen \& Choy, supra note 7, at 332-33.

133. Government Agencies, supra note 14.

134. Id.

135. Id. 
Chinese-Foreign ventures that were not previously in effect. ${ }^{136}$ Because of the growing popularity of blogging, SMS, and bulletin boards, the Administration of News explicitly encompasses these uses. ${ }^{137}$ The previous Internet regulations' applicability to these technologies may have been unclear. ${ }^{138}$

The effects of the Administration of News are expected to be felt more by individuals than existing news organizations, ${ }^{139}$ which is why the regulations have been characterized as being created in response to the growing popularity of blogging. ${ }^{140}$ "The mainstream press in China already follows official sanctions - they self-censor and get their news filtered and censored before publication." 141 News organizations also regularly meet with government officials to learn what news is acceptable to report. ${ }^{142}$ Executives from Internet news providers attend the meetings; representation at the meetings include all of China's Internet "giants" and the Chinese branch of the U.S. corporation Yahoo!. ${ }^{143}$ The Administration of News is significant in that its regulations ensure that "only groups that parrot the government's version of events" will be permitted to post or email news information. ${ }^{144}$ By forbidding any news or political commentary from being posted by individual users, the Administration of News was designed to intimidate bloggers and those who post messages on BBS forums, causing them to avoid controversial subjects. ${ }^{145}$ "The authorities also hope to push the most outspoken online sites to migrate abroad where they will become inaccessible to those inside China because of the Chinese filtering systems." ${ }^{146}$

136. Id.

137. Id.

138. Eugenia Chien, International News Report: China Takes Aim at its Bloggers, ATHENS News, Oct. 6, 2005, http://www.athensnews.com/issue/article.php3?story_id=21758.

139. Id.

140. Hadlock, supra note 15.

141. Chien, supra note 138. The Xinhua News Agency is China's main outlet for propaganda to China's media. REPORTERS WITHOUT BORDERS, XINHUA: THE WORLD's BIGGEST Propaganda AGENCY 2 (2005), http://www.rsf.org/IMG/pdf/Report_Xinhua_Eng.pdf. The international department of Xinhua publishes news internationally that is actually censored inside of China, giving foreign media the impression that China's media has not censored major events. Id. at 6.

142. Stephan Faris, "Freedom": No Documents Found, salon.com, Dec. 16, 2005, http://www.salon.com/tech/feature/2005/12/16/censorship/.

143. Id. Microsoft, which has been criticized for its participation in Party censorship of the Internet, does not attend the meetings because the news on its site in China is provided by a Party publication, the Beijing Youth Daily. Id.

144. End Censorship, supra note 117. Additionally, the Administration of News sets minimum standards that news organizations must adhere to, which makes compliance difficult, if not impossible, for small organizations. Id. They must have registered capital of ten million yuan, and they must have at least ten full-time news editors, five of whom must have at least three years experience in a legal news organization. Administration of News, supra note 89, art. 8. Ten million yuan is approximately $\$ 1.2$ million dollars (USD). Universal Currency Converter, http://www.xe.com/ucc (last visited Dec. 18, 2006).

145. Chien, supra note 138.

146. Authorities Declare War, supra note 106. 
Another regulation of news was promulgated on September 10, 2006, entitled Measures for Administering the Release of News and Information in China by Foreign News Agencies (Release of News). ${ }^{147}$ The regulations do not explicitly apply to Internet news but could encompass it. ${ }^{148}$ The regulations require foreign news agencies to apply to the Xinhua News Agency for permission to distribute news information within China. ${ }^{149}$

The Release of News contains ten categories of forbidden information that foreign news agencies may not include in their articles; the categories are similar to the prohibitions contained in the Administration of News. ${ }^{150}$ Foreign news agencies are also forbidden from soliciting subscription of their news to users in China. $^{151}$ In contrast to the Administration of News, which was characterized as greatly affecting bloggers, ${ }^{152}$ commentators criticize the Release of News as having a "large commercial impact on foreign distributors of financial information, such as Reuters and Bloomberg." 153

\section{c. The Effect of Internet Regulation: Self-censorship}

The blocking of particular websites or the imposition of monetary fines, though important to Chinese Internet regulation, does not have as great an impact on citizens' Internet usage habits as the manner in which the law is enforced. ${ }^{154}$ Enforcement is designed to cause every user and every business in the country to believe that if an Internet law is violated, the violation will be caught and the punishment will be severe. ${ }^{155}$ This causes individuals, ISPs, and ICPs to self-censor. This way, the government does not have to block as much offensive content or locate as many violators because " $[\mathrm{t}] \mathrm{he}$ best censorship is

147. Measures for Administering the Release of News and Information in China by Foreign News Agencies (promulgated by Xinhua, Sept. 10, 2006), translated in CongressionalExecutive Commission on China, Measures for Administering the Release of News and Information in China by Foreign News Agencies, http://www.cecc.gov/pages/virtualAcad/index.phpd?showsingle=69668 (last visited Dec. 18, 2006) [hereinafter Release of News].

148. See id. art. 2 ("These Measures shall be applicable to the release of news and information in text, photo, graphics and other forms in China by foreign news agencies.").

149. Id. art. 4.

150. See id. art. 11.

151. Id. art. 4.

152. See Hadlock, supra note 15.

153. Congressional-Executive Commission on China, New Measures Increase Xinhua Control Over Foreign News Sources, (Oct. 3, 2006), http://cecc.gov/pages/virtualAcad/index.phpd?showsingle=70873. Critics also voiced concern over the ability of foreign news agencies to report on the 2008 Beijing Olympic Games, which Chinese officials had previously promised that reporters would be free to cover. See BBC News, New China Media Curbs Condemned (Sept. 12, 2006), http://news.bbc.co.uk/2/hi/asiapacific/5337248.stm.

154. See generally 2005 Annual Report, supra note 33, at III(e) (describing freedom of expression in China).

155. Id. 
self-censorship . . .,"156

One of the reasons many people choose to self-censor is the fear of imprisonment. ${ }^{157}$ A human rights organization found that between 1998 and 2003, seventy-one people had been arrested in China for using the Internet to access or post political or religious material. ${ }^{158}$ Reporters Without Borders, an advocate for worldwide freedom of the press, estimates that there are currently eighty-six journalists and cyber-dissidents imprisoned in China. ${ }^{159}$ In almost all of the Internet-related imprisonments, the individuals had been charged with subversion, found guilty, and sentenced to between two and twelve years imprisonment. ${ }^{160}$ "The manhunts for individual Internet users, which often mobilize dozens of agents from the public security and state security ministries, serve as warnings for the recalcitrants and dissidents who continue to surf the Internet." 161

Chinese citizens recognize that using the Internet in a way that would violate the law is dangerous due to broad publicity surrounding citizens who are arrested. ${ }^{162}$ In 2005, the arrest of Shi Tao was widely reported. ${ }^{163}$ Shi Tao is a Chinese citizen who used a Yahoo! email address to correspond with the editor of a democracy-promoting website and periodical. ${ }^{164}$ Shi provided the editor, who resides in New York, with information contained in a top-secret government document, which reportedly expressed the Party's concern about the possibility of demonstrations occurring on the fifteenth anniversary of the Tiananmen Square tragedy. ${ }^{165}$ At the CCP's request, Yahoo! identified the

156. Matthew Forney, China's Web Watchers, (Oct. 3, 2005), http://www.time.com/time/magazine/article/0,9171,501051010-1112920,00.html.

157. See generally BOBSON WONG, THE TUG-OF-WAR FOR CONTROL OFCHINA's INTERNET, http://www.hrichina.org/fs/downloadables/pdf/downloadable-

resources/a3_Tugofwar.2004.pdf?revision_id=8986 (last visited Dec. 18, 2006) (describing Chinese citizens who were imprisoned for posting information on the Internet) (hereinafter WONG, TUG-OF-WAR].

158. Id. at 1 .

159. Reporters Without Borders, Journalist Tried for Posting "Alarmist" Reports on Foreign Websites (Jan. 20, 2006), http://rsf.org/article.php3?id_article=16221.

160. WONG, TUG-OF-WAR, supra note 157 , at 1.

161. Living Dangerously, supra note 34.

162. Tim Johnson, In China, Sophisticated Filters Keep the Internet Near Sterile, CHINA DigiTAL TIMES, July 14, 2005, http://chinadigitaltimes.net/2005/07/tim_johnson_in.php; Li, supra note 28 , at 6 .

163. Forney, supra note 156; see also BBC News, Yahoo "Helped Jail China Writer" (Sept. 7, 2005), http://news.bbc.co.uk/go/pr/fr/-/1/hi/world/asia-pacific/4221538.stm; Reporters Without Borders, Information Supplied by Yahoo! Helped Journalist Shi Tao Get 10 Years in Prison (June 9, 2005), htpp://www.rsf.org/article.php3?id_article=14884 [hereinafter Information Supplied].

164. Shi Tao Written Judgment (Hunan Province Changsha Municipality Intermediate People's Court, April 27, 2005) translated in Congressional-Executive Commission on China, Changsha Intermediate People's Court's Written Judgment in the Shi Tao State Secrets Trial, http://www.cecc.gov/pages/virtualAcad/index.phpd?showsingle=19648 (last visited Dec. 19 , 2006).

165. Id.; Information Supplied, supra note 163. 
Internet Protocol (IP) address used to send the message, which allowed the government to locate and arrest Shi. ${ }^{166} \mathrm{He}$ was found guilty of illegally providing state secrets to foreigners and was sentenced to ten years imprisonment. ${ }^{167}$

Another Internet-related conviction in 2005 captured the attention of Chinese Internet users. ${ }^{168}$ Poet and political commentator Zheng Yichun was charged with posting his articles about the "evil" of China's one-party system on a website. ${ }^{169}$ Although Chinese Internet users would not have been able to read his articles because the website had been blacklisted by the Party for some time, Zheng was arrested and sentenced to seven years imprisonment for subversion. ${ }^{170}$ Another Chinese writer who had posted articles on the same website commented that "Zheng's arrest served as a warning to people like me," and he requested that the website take down any information that he had previously posted. ${ }^{171}$

Internet users have always been in danger of arrest if they chose to post information related to the most sensitive topics, such as the Falun Gong spiritual movement or Tiananmen Square. ${ }^{172}$ More recently, however, many citizens have also been detained by the government for posting more general information, such as complaints about Internet cafe restrictions or calls for greater freedom of expression. ${ }^{173}$

Another cause of self-censorship is the vaguely written laws that make it unclear what information the government might deem as subversive, a state secret, or harmful to national interests. ${ }^{174}$ "Such obscurity [in the language of the regulations] gives the government wide discretion[] and a stronger basis on which to arrest and punish persons who engage in [controversial] forms of expression." 175 This causes many people to err on the side of caution rather

166. Information Supplied, supra note 163. For an explanation of how an IP address functions, see infra note 200.

167. Information Supplied, supra note 163. Media reports suggest that Yahoo! has provided information to the CCP in other criminal cases as well, leading to the imprisonment of Jiang Lijun, Liu Di, and Li Zhi. See Grant Gross, Group: Yahoo Help Led to Third Dissident's Arrest (Apr. 19, http://www.infoworld.com/article/06/04/19/77557_HNyahoodob_1.html.

168. Forney, supra note 156.

169. Id.

170. Id.

171. Id.

172. WONG, TUG-OF-WAR, supra note 157 , at 1-2. See Falun Dafa, http://www.falundafa.org/eng/index.htm (last visited Dec. 18, 2006). Falun Gong, or Falun Dafa, is a practice that improves "one's heart and mind through the careful study of universal principles based on truthfulness, benevolence, and forbearance." Id. See also Richard C. Morais, Cracks in the Wall, ForBEs, Feb. 27, 2006, at 94. When the Falun Gong movement spread to seventy million practitioners, the police began to imprison and torture members. Id. The movement has now spread worldwide. Id.

173. WONG, TUG-OF-WAR, supra note 157.

174. Cullen \& Choy, supra note 7, at 332.

175. Li, supra note 28 , at 6 . 
than risk being caught in violation of an Internet regulation. " 176 "Broad, vague, and conflicting legislation hangs over Chinese citizens like a fog, obscuring the boundaries of free speech to such a degree that most people are too wary to approach them for fear of over stepping them." 177 Chinese bloggers feel that freedom of expression is greater than one might expect, but it is not completely free. ${ }^{178}$ One editor of a Chinese magazine who publishes articles that are critical of the government stated, "We go up to the line-we might even push it. But we never cross it."179

Through regulations that hold ISPs, ICPs, and BBS operators liable for content posted on their sites or by using their technology, the Party also induces these entities to self-censor topics that might be deemed illegal. ${ }^{180}$ A media analyst explained:

[T]he Chinese government is currently outsourcing the censorship duties. Finding it impossible to control the opinions of thousands and thousands of bloggers, it is delegating responsibility to a number of favored internet service companies ... who employ a system of self-censorship and delete posts that might be regarded as offensive or politically sensitive. ${ }^{181}$

Other organizations that provide BBS, message boards, or forums for public opinion also must regularly delete posts or risk being shut down. ${ }^{182}$

After an incident of government violence, ${ }^{183}$ one popular bulletin board, Kdnet, was overwhelmed with more than 30,000 messages of "protest and sorrow." "184 The site operator deleted most of the messages but posted an explanation: "Please understand, what other Web sites cannot do, Kdnet also cannot do." " 85 This is a common occurrence; forum operators have developed their own systems, as required by the States Secret Law, ${ }^{186}$ to catch banned

176. Congressional-Executive Commission on China, Prior Restraints in China, http://www.cecc.gov/pages/virtualAcad/exp/exppriorrestraints.php (last visited Dec. 18, 2006).

177. Id.

178. Sumner Lemon, China Finds Freedom Behind Great Firewall (May 27, 2005), http://www.pcworld.com/article/id,1 16278-page,1/article.html [hereinafter Lemon, China Finds Freedom].

179. 2005 Annual Report, supra note 33, at III(e) (citing David Barboza, Pushing (and Toeing) the Line in China, N.Y. TMmes, April 18, 2005, at C1). See also Lemon, China Finds Freedom, supra note 178. "Internet users who post content online . . are generally savvy enough to know what topics test the government's tolerance for free discussion ...." Id.

180. Philip P. Pan, Internet Appears to be Weakening China Government's Control of News, WASH. POST, Dec. 17, 2005, at A1. See also Living Dangerously, supra note 34.

181. Gill \& Stanway, supra note 31 .

182. Id.

183. See infra notes 315-16 and accompanying text.

184. Pan, supra note 180.

185. Id.

186. See supra notes $75-81$ and accompanying text. 
words so that they can review the message before it is posted. ${ }^{187}$

\section{Technological Control}

The CCP complements the legal regulations with technological measures that are used both to enforce the legal regulations placed upon individuals and to block content that the Party deems as inappropriate. ${ }^{188}$

In general, China attempts to suppress publication of information related to "subversive" political movements and controversial state actions, including the Tiananmen Square uprising, support for a free Tibet, the Falun Gong spiritual movement, criticism of China's human rights and social justice records, independent news media, and pro-democracy [or] pro-Western commentary. ${ }^{189}$

The CCP has created "the most extensive, technologically sophisticated, and broad-reaching system of Internet filtering in the world"190 It is difficult to determine exactly how the Party controls the Internet because it changes dynamically over time. ${ }^{191}$ Filtering primarily occurs at the "backbone level" of China's network through the construction of a nationwide firewall. ${ }^{192}$ In addition, ISPs, Chinese search engines, and blog-hosting services, among others, also filter content. ${ }^{193}$ When content is filtered, users sometimes view a "block page," which is a webpage with text identifying that the content may not be accessed. 194 Filtering is often less obvious, however, "appearing to be network errors, redirections, or lengthy timeouts rather than deliberate blocking." 195

Nine backbone Internet network connections exist in China, ${ }^{196}$ and they are required by law to be at least fifty-one percent controlled by State-owned companies. ${ }^{197}$ Because there are few backbone levels and they are state-

187. Living Dangerously, supra note 34. However, moderators at some sites try to "look the other way or drag their feet when they think they can get away with it, because they know that customers are drawn to Web sites with less censorship." Pan, supra note 180.

188. See generally ONI, supra note 36 (describing technological measure of control).

189. Id. at 4-5.

190. Id. at 4 .

191. Id. at 3 .

192. Id. at 3; Liang, supra note 10 , at 1429 . "A firewall is a "computer or group of computer systems that enforces an access control policy between two networks by blocking traffic or permitting traffic." Id. at 1430-31 (quoting William Yurcik \& Zixiang Tan, The Great Fire (Wall) of China: Internet Security and Information Policy Issues in the People's Republic of China, http://www.tprc.org/abstracts/tan.txt).

193. ONI, supra note 36 , at 3 .

194. Id. at 20.

195. Id.

196. Id. at 6.

197. Johnson, supra note 162. 
controlled, it is simple to add filtering code "at the gateways . . . to meet the [CCP's] special requirement for surveillance." 198 All Internet traffic passes through these backbones. ${ }^{199}$ The backbone level of China's network depends on routers made by Cisco, a U.S. corporation. ${ }^{200}$ Cisco routers can easily be configured to block information; for example, Cisco routers are commonly utilized in the United States to block viruses. ${ }^{201}$ The same technique used to block viruses can also be used to deny access to information that the CCP wishes to remain inaccessible. ${ }^{202}$ The version of Cisco routers that was purchased for China's network is capable of handling 750,000 filtering content rules. ${ }^{203}$ It is clear that China's network relies on Cisco routers; a Cisco whistleblower further alleged that Cisco customized and developed a type of router or firewall box specifically for China's specialized filtering needs. ${ }^{204}$ The router hardware and software that Cisco has provided to China is used both to "filter web traffic" and "conduct surveillance of Chinese Internet users.,"205

One method of filtering content achieved at the backbone level is through blocking the IP addresses of websites that the Party does not want citizens to access. $^{206}$ The CCP also filters by domain names or Uniform Resource Locators (URLs). ${ }^{207}$ In 1996, the CCP blocked approximately one hundred websites, including access to U.S. newspapers and websites about Taiwan or Hong Kong. ${ }^{208}$ The number of blocked websites has grown tremendously since

198. Li, supra note 28 , at 7 .

199. Johnson, supra note 162.

200. ONI, supra note 36 , at 6 .

201. Stephanie Ho, Repressive Governments Use U.S. Technology to Control Internet Access (Oct. 13, 2005), http://www.voanews.com/english/archive/2005-10/BKG-HO-InternetCensorship.cfm.

202. ONI, supra note 36 , at 7 .

203. Id.

204. Id.

205. David Kootnikoff, The Great Internet Firewall of China U.S. Tech Companies Are Helping to Obstruct Net Freedom, OHMYNEws, Nov. 21, 2005, http://english.ohmynews.com/articleview/article_view.asp?menu=c10400\&no=259669\&rel_no= 1 .

206. China's State Control Mechanisms and Methods: Testimony Before the U.S. -China Economic and Security Review Commission, 109th Cong. (2005) (statement of Kenneth Berman, Director of Information Technology, International Broadcasting Bureau), available at http://www.uscc.gov/hearings/2005hearings/written_testimonies/05_04_14wrts/berman_kennet h_wrts.htm (last visited Dec. 18, 2006) [hereinafter Berman].

207. Id.; ONI, supra note 36, at 3-4. A domain name is a series of letters and numbers separated by periods that is used as an address of a computer network. TechTerms.org, Domain Name Definition, http://www.techterms.org/definition/domainname (last visited Dec. 18, 2006). For example, the search engine Google has the domain name of google.com. An IP address is a set of numbers that identifies devices on a network. TechWeb, IP Address Definition, http://www.techweb.com/encyclopedia/defineterm.jhtml?term=IPaddress (last visited Dec. 18, 2006). A URL is a standardized address name layout that "indicates what kind of resource it is addressing" and the path to the file. See TechTerms.org, URL (Uniform Resource Locator) Definition, http://www.techterms.org/definition/url (last visited Dec. 18, 2006). For example, the URL for Google's Image Search is http://www.google.com/images.

208. Liang, supra note 10 , at 1430. 
then. ${ }^{209}$ Websites such as Amnesty International, Time Magazine, and news sites by the British Broadcasting Corporation (BBC) are routinely blocked, showing only a message stating "The Page Cannot be Displayed."210

Other sites that contain foreign news, however, are often accessible if they appear in a language other than Chinese. ${ }^{211}$ If the news is translated in Chinese, then the site is often blocked. ${ }^{212}$ The Party has also used domain name system redirection or "hijacking," which takes a user to a website that the Party has chosen rather than the website the user intended. ${ }^{213}$

Filtering of websites has become more refined in the last few years. ${ }^{214}$ One study discovered that, in general, websites were actually more accessible in 2005 than in a previous study completed in $2002 ;{ }^{215}$ however, websites that used the Chinese terms for "Falun Gong" and "Tiananmen Event" were "consistently less accessible in 2005." 216 The researchers concluded that there "appears to be greater specificity and better targeting by China's filtering system" than in previous years. ${ }^{217}$ It appears that websites have become more accessible because China has better "tuned its filters" to allow access to some general information on topics relating to forbidden subjects; for example, general information about Tibet may be accessible now, but politically sensitive material about Tibet is still primarily inaccessible. ${ }^{218}$ Fewer foreign news sites are blocked than in the past, and it is now "individual bloggers, rather than the New York Times, who are more likely to be blocked.,219

Initially, the CCP blocked entire domains; however, various domains have been partially unblocked and have some accessible and some inaccessible URLs. ${ }^{220}$ For example, the BBC website was initially blocked entirely; now Chinese users can access parts of the website, such as entertainment articles. ${ }^{221}$ The CCP will tolerate over-blocking of acceptable content, however, if the domain is likely to have mixed content, where some content is forbidden and some content is acceptable. ${ }^{222}$ For example, the entire domains of Angelfire, Blogspot, Tripod, and Geocities were found to be entirely inaccessible in one study; these domains all provide free web-hosting or blogging capabilities. ${ }^{223}$

The CCP has also filtered the results that search engines display to ensure

209. See generally ONI, supra note 36.

210. Johnson, supra note 162.

211. Gill \& Stanway, supra note 31 .

212. Id.

213. Berman, supra note 206.

214. ONI, supra note 36 , at 4 .

215. Id. at 36 .

216. Id. at 35 .

217. Id.

218. Id. at 36.

219. Gill \& Stanway, supra note 31 .

220. ONI, supra note 36, at 38 .

221. Id. at 3; Newbold, supra note 18, at 511.

222. ONI, supra note 36 , at 40.

223. Id. 
that illegal information is not viewed..$^{224}$ In 2002 , access to the search engine Google was blocked after the CCP discovered that it could be used to access forbidden material, such as websites about the Falun Gong spiritual movement or Tibetan independence. ${ }^{25}$ After a large public outcry, access to Google was later restored, but the caches remained blocked and the results are filtered by the CCP. ${ }^{226}$ "Internet searches inevitably yield 'error' messages" when used to look for forbidden information. ${ }^{27}$ If users search for prohibited words or phrases, they are "put in a virtual 'penalty box' that temporarily locks up a computer's browser." 228 More than one consecutive illegal search may cause the computer to entirely freeze, requiring it to be rebooted. ${ }^{229}$

In January 2006, Google introduced a new search engine for China, ${ }^{230}$ prompting criticism from Western organizations. ${ }^{231}$ Previously, Chinese users were accessing the Chinese-language version of Google.com, but now they can access Google.cn. ${ }^{232}$ The search engines differ in that Google now cooperates with the Party to block illegal content on Google.cn rather than the Party imposing the censorship. ${ }^{233}$ Thus, users will no longer face the lengthy timeouts and error messages they experienced before, but the results will still be censored. ${ }^{234}$ When searching for sensitive topics on the new Google site, most results displayed are government sites or those with the Chinese suffix ".cn." Because all ".cn" websites are subject to the Registration Measures, ${ }^{236}$ the CCP can ensure that the search engine yields only acceptable information.

Other systems have been implemented by the CCP that do not directly block or filter content but nevertheless ensure that legal regulations are being followed. ${ }^{237}$ After the promulgation of the Registration Measures, which

224. See, e.g., Newbold, supra note 18 , at 509 .

225. Id.

226. Elaine M. Chen, Legislative Update: Global Internet Freedom: Can Censorship and Freedom Coexist?, 13 DePAUL-LCA J. ART \& ENT. L. 229, 239 (2003); Living Dangerously, supra note 34. A cache "stores recently-used information" so that a user can easily access it. TechTerms.org, Cache Definition, http://TechTerms.org/definition/cache (last visited Dec. 19, 2006). The search engine Google "takes a snapshot of each page examined ... and caches these as a back-up in case the original page is unavailable." Google, Google Help: Search Features, http://www.google.com/help/features.html\#cached (last visited Dec. 19, 2006).

227. Johnson, supra note 162.

228. Id. Penalties last approximately "one hour for the first violation, two hours for the second, and a day for the third." Berman, supra note 206.

229. Johnson, supra note 162.

230. Christopher Bodeen, Google Launches Censored China Site (Jan. 25, 2006), http://abcnews.go.com/Technology/wireStory?id=1542343.

231. Luis Ramirez, Press Freedom Advocates Blast Google's Decision to Censor Itself in China (Jan. 25, 2006), http://www.voanews.com/english/archive/2006-01/2006-01-25voa5.cfm.

232. Bodeen, supra note 230.

233. Id.

234. Id.

235. Id.

236. See supra note 93 and accompanying text.

237. See, e.g., Authorities Declare War, supra note 106. 
required websites to be registered and the registration number to appear on the site, the MII announced the deployment of a new system that checks the web for unregistered websites. ${ }^{238}$ The system, called "Night Crawler," allows the government entity to "locate and block unregistered websites"239 by "monitor[ing] the sites in real time and search[ing] each Web address for its registration number." 240 To further ensure that forbidden content remains inaccessible and legal regulations are followed, the CCP employs an estimated 30,000 people to personally monitor and censor the Internet. ${ }^{241}$ Teams of people have been established within departments of public security to monitor and censor websites. ${ }^{242}$

An innovative method of encouraging citizens to comply with the legal regulations was introduced in January 2006 when the city of Shenzhen introduced two Internet police cartoon characters, Jinging and Chacha, who appear on all websites and web forums of Shenzhen. ${ }^{243}$ The cartoons move interactively with the users as they navigate through web pages. ${ }^{244}$ The cartoons function as links to information about Internet regulations and Internet crime cases; they can also connect users to actual Internet police through an Instant Messaging (IM) service for the purpose of answering users' questions about Internet security. ${ }^{245}$

Officials of the Shenzhen Public Security Bureau informed reporters, however, that the "main function" of the cartoons is "to intimidate, not to answer questions. . .."246 Local authorities reported that between January and May 2006 the frequency of posting "hazardous information" decreased by sixty percent, and more than 1600 Internet crime allegations were reported through the cartoon police. ${ }^{247}$ Within five months of their introduction, the cartoon police were deemed a success and were scheduled to be introduced in eight other cities. ${ }^{248}$

Filtering is also done at levels other than the backbone level and by

238. Id.

239. Id.

240. Assoc. Press, China Orders All Blogs to Register (June 7, 2005), available at http://www.msnbc.msn.com/id/8131497 [hereinafter Blogs to Register].

241. Living Dangerously, supra note 34.

242. Id.

243. Xiao Qiang, Image of Internet Police: JingJing and Chacha Online - Hong Yan (Jan. 22 , 2006),

http://www.chinadigitaltimes.net/2006/01/image_of_internet_police_jingjing_and_chacha_onlin e_hon.php. "Jingcha" is the Chinese word for "police." Id.

244. Id.

245. Id.

246. Id.

247. Xinhua, Cyber Police in Shenzhen to Curb On-Line Crimes (May 15, 2006), http://news.xinhuanet.com/english/2006-05/15/content_4547731.htm.

248. Michael Zhao, Online Police to Expand from Shenzhen to 8 Other Cities - An Ling (May 14 , 2006),

http://chinadigitaltimes.net/2006/05/online_police_to_expand_from_shenzhen_to_8_other_citie s.php. 
entities other than the CCP. ${ }^{249}$ For example, the MSN Spaces blog-hosting service has received international attention because it prevents bloggers from using politically sensitive language in the names of the blogs or in the titles of blog entries. ${ }^{250}$ The blocking is done through the identification of keywords or phrases that are forbidden, such as "Taiwan independence," "human rights," "freedom," or "democracy."251 When a user has attempted to name a blog or an entry using a banned word, the blogger will receive a message stating: "This message contains a banned expression, please delete this expression."252

MSN responds that, as a corporation, it "abides by the laws, regulations[,] and norms of each country in which it operates."253 A Chinese blogger and technology entrepreneur noted that although official Chinese censorship practices ban speech that is critical of the government, there is no law forbidding the use of words like "freedom"; therefore, MSN is actually going beyond the "laws, regulations[,] and norms" of the country by denying all use of the word. ${ }^{254}$ MSN was also severely criticized for acquiescing to Party demands and deleting a blog that was critical of the CCP's removal of a newspaper editor in December 2005. ${ }^{255}$ Even a Microsoft employee spoke out against the action by his company, stating: "It's one thing to pull a list of words out of blogs using an algorithm. It's another thing to become an agent of a government and censor an entire blogger's work."256

The methods imposed by the CCP and by ISPs or ICPs effectively censor many types of content. Although many Chinese citizens do not support censorship of political information, the majority of citizens are in favor of blocking certain types of content, such as pornography, violence, and unsolicited commercial emails (spam). ${ }^{257}$ A Chinese blogger wrote that "the western world is focused on freedom of speech and media in China, but [is] not addressing any problems with imposing socio-cultural standards (with respect to pornography, for example) on everybody else."258 In general, the CCP has

249. See, e.g., Kevin Poulsen, Chinese Blogger Slams Microsoft (June 20, 2005), http://www.wired.com/news/technology/1,67957-0.html.

250. Id.

251. Id.

252. BBC News, Microsoft Censors Chinese Blogs (June 14, 2005), http://news.bbc.co.uk/2/hi/technology/4088702.stm.

253. Poulsen, supra note 249.

254. Id.

255. David Barboza \& Tom Zeller Jr., Microsoft Shuts Blog's Site After Complaints by Beijing, N.Y. TIMES, Jan. 6, 2006, at C3, available at 2006 WLNR 325978.

256. Id.

257. Antone Gonsalves, Chinese Web Users Slow to Buy, Quick to Have Fun (Nov. 17, 2005), http://informationweek.com/story/showArticle.jhtml?articleID=174400176. See also Bobson Wong, A MatTer of Trust: THE INTERnet and Social Change in China 2 (2003), available at http://www.hrichina.org/public/contents/10351 (last visited Dec. 18, 2006) [hereinafter WONG, MATTER OF TRUST]. "[C]ensorship is neither as extreme nor as unpopular in China as many Westerners might think." Id.

258. Hinano Mizuki, The Case for Internet Censoring in China, translated in EastSouthWestNorth (June 22, 2005), http://www.zonaeuropa.com/20050622_1.htm. 
effectively censored pornography, ${ }^{259}$ and it has also sought to eliminate violent web-based video games, spam, fraud, and gambling. ${ }^{260}$ The Party also censors other information that its citizens may not be fully aware of, such as information about Taiwan or Tibet. ${ }^{261}$ "[In a country such as China,] sometimes a product gets sold or implemented and [citizens] don't even know what [types of content] they're not getting or why. ${ }^{, 262}$

Although the technology used to censor content is highly sophisticated and effective, the technological methods of content control are not foolproof, as discussed in Part B. Sophisticated users are able to find ways around the various methods of technological control. ${ }^{263}$

\section{Access Control}

The third method that the CCP uses to maintain control of the Internet is through creating a system of control that makes it more difficult for citizens to access the Internet. ${ }^{264}$ The government regulates access control through two primary methods: mandatory registration of individuals ${ }^{265}$ and regulation of the Internet cafes. ${ }^{266}$

"Access control has always been a part of China's Internet filtering system. ..."267 Regulation of individuals who use the Internet began in 1996 and has been updated several times. ${ }^{268}$ The regulations require citizens to obtain licenses for Internet access and register with the local police, providing their names, the names of their service providers, their e-mail addresses, and any newsgroups to which they subscribe ${ }^{269}$ Through regulations promulgated in 2000, the CCP required ISPs to track their users' account numbers, when their users are online, and the sites their customers visit. ${ }^{270}$ Regardless of whether the CCP actually uses this identification information to sanction individuals, the requirements of providing personal information is designed to give citizens the impression that "every bit of [their] activity is tracked."271

Local and province officials have also used their authority to require individuals using BBS, chat rooms, and IM services to use their real names

259. ONI, supra note 36, at 37; Carpenter, supra note 11.

260. Assoc. Press, China Winning War on Internet Pornography (Dec. 29, 2005), http://www.chinadaily.com.cn/english/doc/2005-12/29/content_507774.htm.

261. ONI, supra note 36 , at 4 .

262. Carpenter, supra note 11.

263. Faris, supra note 142.

264. See, e.g., Reed, supra note 1 , at 462 .

265. Id.

266. Newbold, supra note 18, at 504.

267. ONI, supra note 36 , at 9.

268. Reed, supra note 1 , at 462 .

269. Id.

270. ONI, supra note 36, at 11.

271. Johnson, supra note 162 . 
when posting messages or chatting online. ${ }^{272}$ Although the real name system is not currently a national law, it has been used in some provinces and in university settings since $2003 .{ }^{273}$ In July 2005 , the real name system was enforced upon administrators and group founders of $Q Q$, which is China's largest IM service. ${ }^{274}$ A notice posted on QQ explained the need for the real name system: "This year, at various Internet chat rooms in our city, there were chat groups, forums, BBS, Internet SMS, and various Internet public information services in which there were illegal assemblies, illegal alliances[,] and obscene behaviors being observed."275 Requiring registration of all Internet users and implementing real name systems are two more techniques of creating and enforcing user accountability for Internet content control. ${ }^{276}$

The second method the CCP uses to manage Internet access is regulation of Internet cafes. ${ }^{277}$ Control of Internet cafes is critical for the CCP because many Chinese citizens are unable to afford a personal computer, and they use Internet cafes as the primary method for gaining Internet access. ${ }^{278}$ Regulation of Internet cafes became significantly more stringent after a fire in an Internet cafe killed twenty-five people in $2002 .{ }^{279}$ Prior to the fire, Internet cafes had already been subject to regulation; "tens of thousands" of cafes had been shut down in the preceding years. ${ }^{280}$ As a result, many cafes were operating without the required licenses, and the owners of the cafe in which the fire occurred had barred the doors at night while customers were inside, due to fear of government inspection. ${ }^{281}$ When a fire broke out, some of the customers inside the cafe were unable to escape. ${ }^{282}$

Shortly thereafter, the CCP imposed even stricter regulations for licensing of the cafes, bans on minors using the cafes, and requirements for operators. ${ }^{283}$ The operators must install filtering software, post signs warning users not to access illegal information, register users, keep records of the users' activity for sixty days, and provide that information to the CCP upon request. ${ }^{284}$ They must also apply for a fire safety permit and demonstrate that they have adequate security personnel. ${ }^{285}$ Subsequent to the fire, the Party shut down 150,000

272. China Tightens Grip, supra note 32.

273. Id.

274. Fourteen Departments, supra note 13. There are 100 million active users of QQ, which includes 8 million users who are classified as founders and administrators. Id.

275. Id.

276. See China Tightens Grip, supra note 32.

277. Newbold, supra note 18, at 504.

278. Ang, supra note 2.

279. Fourteen Departments, supra note 13.

280. Newbold, supra note 18 , at 504.

281. Id.

282. Id.

283. Id. at 510 .

284. Id. The filtering software, known as "Internet Police 110 " blocks more than 500,000 banned websites. Id.

285. ONI, supra note 36, at 12. 
unlicensed Internet cafes between June and September 2002. ${ }^{286}$ In 2004, the Party shut down 47,000 Internet cafes, sanctioned 21,000 , and revoked the licenses of more than 2000 others. ${ }^{287}$

A journalist provided a description of what it was like to use an Internet cafe in Shanghai:

Each incoming user must give a name and address, then hand over identification to a clerk. Closed-circuit TV cameras monitor from overhead. Every computer terminal is loaded with software to track all activity. If a user heads toward a prohibited Web site, cafe employees know right away ... [because a] blinking light goes off. ... The software also alerts authorities at a Shanghai municipal security post across town, and inspectors eventually may drop in to check on the infractions. ${ }^{288}$

Even though Internet cafe use is highly regulated, this does not deter Chinese citizens from using the cafes. ${ }^{289}$ One journalist remarked, "[A]t 1 [a.m.] in a Beijing internet cafe there is not an empty seat, as in most of the other 100,000 internet cafes in China." ${ }^{, 290}$ Therefore, despite the strict regulation, Chinese citizens still find the Internet a useful and viable medium, as demonstrated by the skyrocketing number of Chinese citizens who use the Internet. ${ }^{291}$

The Party has fairly effectively controlled the Internet through three forms of control: legal control to create accountability through criminal and civil liability, technological control to prevent access to controversial information, and access control to closely monitor citizens who use the Internet. It is clear that the CCP has created stringent forms of control over the Internet. As technology evolves, the methods of control that the CCP employs will also need to evolve. Although the technology continues to change, there are certain reasons that the CCP controls the Internet which remain the same. The next section of this Note will explore why the Party finds it necessary to regulate in the manner it does.

286. Alfred Hermida, Behind China's Internet Red Firewall (Sept. 3, 2002), http://news.bbc.co.uk/1/hi/technology/2234154.stm.

287. Petra Räisänen, The Urban Technospace: A Study on Internet Cafes in Shanghai 16 (Spring 2006) (unpublished Master's thesis, Lund University), available at theses.lub.lu.se/archive/2006/08/15/1155639224-21264-493/description.scr (last visited Dec. $18,2006)$.

288. Johnson, supra note 162.

289. Poppy Sebag-Montefiore, China's Young Escape into the Web (Nov. 20, 2005), http://observer.guardian.co.uk/international/story/0,6903,1646663,00.html.

290. Id.

291. See 111 Million, supra note 2. 


\section{B. CHARACTERISTICS OF THE INTERNET THAT CAUSE THE CCP TO STRICTLY REGULATE IT}

The President of China stated what he saw as the principle for Internet development in China: "Develop it positively; Strengthen the management; Hasten the benefits while avoiding the harm; and Make it useful for us."292 The Party has recognized that Internet development is essential to its economic growth and global political power. ${ }^{293}$ Therefore, the government must strike a balance between encouraging the expansion of the Internet while controlling its use. ${ }^{294}$

There are many characteristics of the Internet that cause the CCP to regulate it. Indeed, many countries of the world have some type of legislation that relates to the Internet, although most countries do not regulate the Internet to the extent that China does. ${ }^{295}$ The stability of the CCP depends on "maintaining ideological unanimity." ${ }^{296}$ This causes the Party to create and enforce strict Internet regulations in order to minimize negative information about the Party, which the Internet is uniquely suited to spread. ${ }^{297}$ The characteristics of the Internet that necessitate strict regulation by the Party include the accessible nature of information on the Internet, ${ }^{298}$ the anonymous character of posting and accessing information, ${ }^{299}$ the rapidly changing technology that makes control more difficult, ${ }^{300}$ and efforts by Western parties to assist Chinese users in circumventing the control mechanisms. ${ }^{301}$

\section{Nature of the Internet}

When the Internet was first introduced in China, many people predicted that because of the open nature and accessibility of information on the Internet, the political structure of China would ultimately have to change. ${ }^{302}$ Former U.S. President Bill Clinton commented on the nature of the Internet, stating in 2000: "[T]here's no question China has been trying to crack down on the

292. $\mathrm{Li}$, supra note 28 , at 2 .

293. Id.

294. See id.

295. Id. at 3-4.

296. Cullen \& Choy, supra note 7, at 336.

297. Id.

298. Liang, supra note 10 , at 1427.

299. See, e.g., Honan, supra note 3 (describing how the sharing of sensitive information often occurs in chat rooms or on bulletin boards, in part, because of the user's ability to remain anonymous).

300. Gill \& Stanway, supra note 31.

301. See, e.g., Nart Villenueve, Technical Ways to Get Around Censorship, in REPORTERS WITHOUT BORDERS, HANDBOOK FOR BLOGGERS AND CYBER-DISSIDENTS 63-78 (2005), available at http://www.rsf.org/IMG/pdf/handbook_bloggers_cyberdissidents-GB.pdf [hereinafter HANDBOOK FOR BLOGGERS].

302. David Lee, Multinationals Making in a Mint from China's Great Firewall, S. CHINA MORNING POST, Oct. 2, 2002, at 16, available at 2002 WL 4489164. 
Internet - good luck. That's sort of like trying to nail Jello [sic] to the wall." The Internet presents "a unique challenge" to the Party's ability to strictly control the accessibility of certain information because the Internet is designed to be "decentralized and subject to no singular center of authority.",304

One of the primary reasons for the popularity of the Internet "is its power to facilitate instantaneous communication without being subject to any significant constraints." 305 Therefore, the nature of the Internet itself is the key reason the Party must exert such stringent control over it. ${ }^{306}$ Fundamental conflicts between a one-party political system and the nature of the Internet cause the CCP to be "over-sensitiv[e]" about the political implications of the Internet. ${ }^{307}$ The Party has legitimate cause for concern; many organizations use the Internet to try to provide more open communication with Chinese citizens. $^{308}$

In addition to the Party's concern about the accessibility of controversial information, another problem with the nature of the Internet is that it is designed to adapt to faults within the system. "When a link or computer fails, packets adapt and automatically reroute. To access blocked information, a user can just find an alternate route."310 Furthermore, any system of technological censorship can only be effective "to the extent that human behavior is completely predictable."311 For example, when Google implemented the Chinese version of its search engine, users could type into the image search function the term "Tiananmen" and find idyllic pictures of Tiananmen Square. ${ }^{312}$ If the user misspelled the search term "Tianenmen," however, then the famous picture of a student protester facing down a row of armored tanks is included in the search results. ${ }^{313}$ Unless the CCP or Google can predict every potential misspelling of sensitive words, information of this type may often inadvertently be accessible.

Similarly, the CCP must be able to predict the words and phrases that would lead to controversial information. The spread of news of a recent violent

303. Li, supra note 28 , at 4 .

304. Liang, supra note 10 , at 1427.

305. Cullen \& Choy, supra note 7 , at 326.

306. Id.

307. Id.

308. See infra notes $410-17$ and accompanying text.

309. Liang, supra note 10 , at 1428.

310. Id.

311. Id.

312. Owen Thomas, Google's Chinese Censorship Efforts Tank (Jan. 30, 2006), http://money.cnn.com/2006/01/30/technology/browser0130/?cnn=yes.

313. Id. The picture is famous to the Western world. Most Chinese citizens do not speak of Tiananmen Square. See Lisa Rose Weaver, China's Young Ignore Tragic Tiananmen (June 1, 2001), http://edition.cnn.com/2001/WORLD/asiapcf/east/05/31/tiananmen.luo.daiyou/. Those Chinese citizens who are interested in the Tiananmen tragedy probably have not been able to see the picture because of Internet filtering. See Forney, supra note 156 . Recently a Beijing reporter used a proxy server to view, for the first time, a video of the student protestor. Id. He commented, "See that boy facing down a line of tanks? ... I'd heard about that." Id. 
occurrence shows how the nature of the Internet makes it difficult for the CCP to predictably and effectively control content. ${ }^{314}$ On December 6, 2005, government authorities shot and killed an estimated twenty rural protesters in the town of Dongzhou. ${ }^{315}$ The CCP then barred newspapers, broadcasters, and major Internet sites from mentioning the event. ${ }^{316}$ The media blackout was fairly effective because most Chinese citizens did not hear about the killings. ${ }^{317}$ Some Chinese citizens did learn about it, however, and "[found] ways to spread and discuss the news on the Internet, circumventing state controls with e-mail . . . instant messaging . . . blogs and bulletin board forums."318 One example of citizens circumventing Party control was through an online discussion about the killing that was disguised as a discussion about another topic; controversial keywords and other filtering mechanisms were completely avoided. $^{319}$

At first glance, it looked like a spirited online discussion about an essay written 80 years ago by modern China's greatest author. ... But why did thousands of people read or post notes in an online forum devoted to the essay last week? A close look suggests an answer that China's governing Communist Party might find disturbing: They were using Lu's essay about the 1926 massacre as a pretext to discuss a more current and politically sensitive event - the ... police shooting of rural protesters in ... Dongzhou. ${ }^{320}$

A filtering device would not have the subtlety to recognize that the forum topic contained banned information. Mechanisms for censorship are also generally unable to recognize banned words that users have altered by adding dashes, asterisks, or other characters. ${ }^{321}$ These are two likely reasons why the CCP has found it necessary to employ an estimated 30,000 individuals to personally check websites. ${ }^{322}$

314. See Pan, supra note 180.

315. Id. See also Human Rights Watch, China: Dongzhou Killings Need Independent Investigation (Dec. 15, 2005), http://www.hrw.org/english/docs/2005/12/15/china12281.htm [hereinafter Dongzhou Killings]. Villagers were protesting inadequate compensation for land that had been expropriated for a power plant. Id. Witnesses reported that security forces opened fire without warning. Id. The Party initially claimed the violence was initiated by the villagers, but later stated that a government officer mishandled the incident and caused the "mistaken deaths and accidental injuries." Id.

316. Pan, supra note 180. See also Dongzhou Killings, supra note 315. It was reported that Dongzhou was subsequently sealed off by roadblocks to keep journalists out. Id.

317. Pan, supra note 180.

318. Id.

319. Id.

320. Id.

321. See ONI, supra note 36 , at 48.

322. See Living Dangerously, supra note 34. 


\section{Anonymity}

Another characteristic of the Internet that causes the CCP to strictly regulate it is the anonymity that the Internet provides for its users. ${ }^{323}$ From the first efforts to regulate the Internet, in which citizens had to register with the government in order to access the Internet, ${ }^{324}$ the Party has repeatedly been striving toward the elimination of Chinese citizens' ability to access and post information anonymously; each successive law has taken another step in eradicating the anonymous character of the Internet. ${ }^{325}$

The ability to remain anonymous while surfing the Internet could cause users to seek out forbidden types of information that the Party does not want them to access; ${ }^{326}$ this is another reason for the Party's need to strictly regulate the Internet. Therefore, the CCP requires that ISPs track the sites their customers visit $^{327}$ and that Internet cafes install filtering software. ${ }^{328}$ The CCP has demonstrated to its citizens, through the arrest and imprisonment of Shi Tao, that even the email that individuals write is not anonymous. ${ }^{329}$

The Party is not only concerned with the ability to access information but also the ability to anonymously post information on the Internet. It has attempted to counteract this by requiring both commercial and non-commercial websites to register. ${ }^{330}$ Province officials have even begun to require BBS and IM users to use their real names. ${ }^{331}$ From the CCP's perspective, eliminating the anonymity of the Internet is helpful because it quells some of the rebelliousness that users would otherwise voice if they had the ability to remain anonymous. 332 "Dissent more often shows its face in these forums that are harder for the government to monitor and control."333 Information that the CCP has forbidden is more often distributed in chat rooms and on bulletin boards, which are "places that offer greater levels of anonymity or impermanence." 334

An Internet blog forum called Bokee uses a list of keywords to catch illegal posts. ${ }^{335}$ The operator of the forum stated that ten out of about four

323. See generally Honan, supra note 3 (noting that sites that offer increased "anonymity or impermanence" are often used to post sensitive information).

324. Feir, supra note 58 , at 370 .

325. See, e.g., 2000 Measures, supra note 51; Registration Measures, supra note 93; Administration of News, supra note 89.

326. See generally Living Dangerously, supra note 34 (describing sensitive topics that are removed from Internet forums).

327. 2000 Measures, supra note 51 , art. 14.

328. Newbold, supra note 18 , at 510 .

329. Information Supplied, supra note 163. See supra notes 163-67 and accompanying text.

330. 2000 Measures, supra note 51, art. 4; Registration Measures, supra note 93, art. 3.

331. China Tightens Grip, supra note 32.

332. Honan, supra note 3.

333. Id.

334. Id.

335. Faris, supra note 142. 
hundred people are employed at Bokee to search through blogs to find forbidden information that the filters did not catch. ${ }^{336}$

"[Censoring blogs] is not as serious of a [technical] challenge as people think".... For most of Bokee's blogs, the audience is small and the author can be held accountable, so fewer than one in 500 postings needs to be deleted. On bulletin boards, which are anonymous and reach a larger audience, the number is closer to one in $20 .^{337}$

Creating a system of accountability is thus the Party's most effective way of combating an Internet that is by nature anonymous.

\section{Changing Technology}

The constant development of new technologies is another characteristic of the Internet that results in the CCP's strict Internet regulation. ${ }^{338}$ It is difficult to control a medium that changes so frequently. ${ }^{339}$ When citizens adopt new technology for purposes that the Party deems unacceptable, the CCP must always scramble to catch up. ${ }^{340}$ China is trying to manage the "media explosion brought about by the Internet . . . by aiming to replicate its controls over traditional media through the use of filters, firewalls[,] and complicated registration procedures;", ${ }^{441}$ however, using these old forms of control in a new form of media has created a "considerable challenge" to the authorities. ${ }^{342}$

Blogs are not a new technology per se, but they are a new use of Internet technology. ${ }^{343}$ Chinese blogs have existed since at least $2002^{344}$ and have become extremely popular. ${ }^{345}$ Experts indicate that the sudden growth in popularity of blogs results from more prevalent broadband Internet access and marketing by Chinese Internet providers who promote blogging capability. ${ }^{346}$ Early bloggers exercised discretion, emphasizing its use as a system of information management and deemphasizing the potential for blogging to be used as an "engine for free speech."347 Therefore, blogs were not immediately the source of Party scrutiny even though the CCP already censored or blocked

336. Id.

337. Id.

338. Gill \& Stanway, supra note 31.

339. Feir, supra note 58 , at 385.

340. Blogs to Register, supra note 240.

341. Gill \& Stanway, supra note 31.

342. Id.

343. See generally Thompson, supra note 3 (timeline showing history of blogging).

344. Poulsen, supra note 249.

345. Howard W. French, A Party Girl Leads China's Online Revolution, N.Y. TimEs, Nov. 24, 2005, at A1.

346. Id.

347. Honan, supra note 3. 
personal websites. ${ }^{348}$ However, blogging has "exploded in recent months, challenging China's ever vigilant online censors and giving flesh to the kind of free-spoken civil society whose emergence the government has long been determined to prevent or at least tightly control." 349 The government now recognizes that blogs can be a source of government dissent and thus finds this new use of Internet technology necessary to regulate. ${ }^{350}$

Part of the CCP's concern stems from the freedom of expression associated with blogging. ${ }^{35}$ An entertainment journalist, Wang Xiaofeng, commented on the nature of blogs: "In blogging I don't need to be concerned about taboos ... I don't need to borrow a euphemism to express myself. I can do it more directly, using the exact word I want to, so it feels a lot freer., ${ }^{, 352}$

The Party has demonstrated that it is concerned about blogging; therefore, blogging may not be as free as it seems. ${ }^{353}$ One popular blogger, Isaac Mao, writes primarily about education and technology. ${ }^{354}$ He stated that although he does not avoid particular subjects, he does "try to avoid sensitive words." Mao crossed the line when he posted a graphic that professed to explain how China's firewall system worked. ${ }^{356}$ His blog was blocked by Chinese censors ${ }^{357}$ and is no longer accessible worldwide. ${ }^{358}$ Because some Internet users have been imprisoned for the content they posted, the advocacy group Reporters Without Borders commented, "You have to be brave to publish political content online. ... It's not a hobby."359

Overall, most of the topics posted on blogs in China are not controversial. ${ }^{360}$ Most blog posts are typically politically neutral and often focus on daily life; students also frequently write blogs to practice their English language skills. ${ }^{361}$ Blogs that discuss news and politics, however, are not uncommon." 362 any people "scour foreign Web sites and report on their

348. Id.

349. French, supra note 345.

350. Hadlock, supra note 15.

351. Authorities Declare War, supra note 106.

352. French, supra note 345.

353. See id.

354. Id.

355. Honan, supra note 3.

356. French, supra note 345.

357. Id.

358. Isaac Mao then created a new blog, in which he wrote:

It's been 10 months from the last post when my web site was unplugged and then rejected of registraiton [sic] by authority for [sic - four?] times. . . . Seems no other choices [sic], I have to move this site and blogs to oversea's [sic] hosting at last. It's not my personal intention . . . I I want to keep the site in China.

Isaac Mao, Isaacmao.com Is in Recovering. .., (June 21, 2006), http://www.isaacmao.com/meta.

359. Ho, supra note 201.

360. Honan, supra note 3.

361. Id.

362. French, supra note 345. 
findings, adding their own commentary, in Chinese blogs."363 The sites that provide news, controversial political topics, or have available public forums are subject to censorship, often within minutes or hours, demonstrating the CCP's fear of the new medium. ${ }^{364}$ In March 2004, four of the leading blog providers in China were temporarily shut down. ${ }^{365}$ Users complain that this is typical; there are no stable blogging services because the service provider must completely shut down "when the government finds any sensitive information on any of the 100,000 blogging users' pages."366 The blogs may be restored when the sensitive content has been removed. ${ }^{367}$

The Party must constantly update both the laws and the technological methods of enforcing the laws in order to keep up with the adoption of new technology. ${ }^{368}$ Although blogging has become extremely popular in China, "it still takes a backseat to SMS and other means of peer-to-peer communication." ${ }^{369}$ In December 2005, the MII announced that it would soon require registration of mobile phones because of the "spread of rumors and false advertising" through SMS. ${ }^{370}$ The MII also reported that mobile phone registration would help control "improper political commentary." 371 It takes a certain period of time for an emerging technology to become popular enough for the CCP to become concerned about it, so there is necessarily a delay between popular adoption of a new technology and strict regulation of it. ${ }^{372}$

\section{Internet as a Tool for Mobilization}

The CCP is not just concerned with the information that is accessible

363. Id.

364. See Living Dangerously, supra note 34. But see Nicholas D. Kristof, In China It's ******* vs. Netizens, N.Y. TIMES, June 20, 2006, at A17. A journalist created two Chinese blogs and "huff[ed] and puff[ed] as outrageously" as he could about various sensitive political topics in attempt to see how long it would take for his sites to be shut down. Id. Forbidden words in his posts appeared with asterisks in them, but the sites were not quickly blocked. Id. Another journalist reported that the Chinese blogs written by The New York Times journalist had been blocked the next morning, demonstrating "how difficult it is for [the CCP's] Internet censors to keep up." David Fickling, Beating China's Censors at Their Own Game (June 21, 2006),

http://blogs.guardian.co.uk/news/archives/2006/06/21/beating_chinas_censors_at_their_own_ga me.html.

365. Honan, supra note 3. The domains temporarily closed down were Blogbus, BlogCN, Blogdriver, and TypePad. Id.

366. Id.

367. Id.

368. See generally 2000 Measures, supra note 51; Registration Measures, supra note 93; Administration of News, supra note 89.

369. Honan, supra note 3.

370. China Wants Mobile Phone Users to Register, XINHUA FINANCLAL NETWORK NEWS, Dec. 2, 2005 .

371. Id.

372. See generally Honan, supra note 3 (explaining that the CCP did not initially recognize the significance of blogs and did not censor them until blogging became popular). 
online. ${ }^{373}$ The Party has demonstrated that it has recently become concerned with the Internet's ability to be used for coordinating protests. ${ }^{374}$ The Administration of News regulations added two forbidden categories of information that were not previously prohibited from being posted on the Internet. $^{375}$ Both prohibitions are directed at avoiding civil unrest through prevention of "inciting illegal assemblies, associations, marches, demonstrations, or gatherings that disturb social order" or conducting activities in the name of an "illegal civil organization.",376 The regulations reveal a concern by the CCP that the Internet may be used for those activities. As one commentator stated, "Most foreign analysts get it wrong. . . . Political concern about the Internet [in China] is totally about social organization, not about information. It [is] how you act on the information you have."377

In the Spring of 2005, bulletin board postings and SMS messages motivated thousands of youth to participate in anti-Japanese protests, which caught riot police off-guard. ${ }^{378}$ The CCP recognized the role technology played in instigating the demonstration, so the Party sent SMS messages of its own, warning residents to "avoid illegal demonstrations and to focus their patriotism on their studies and jobs." 379 Public protests like this are a growing trend. ${ }^{380}$ In 2005, "mass gatherings to disturb social order" rose by thirteen percent as compared to $2004{ }^{381}$ Because the Internet can facilitate these mass gatherings, the CCP must govern it more closely to prevent civil unrest. ${ }^{382}$

\section{Sophisticated Users}

The CCP also finds it necessary to regulate the Internet because sophisticated users are able to bypass the technological means of control. ${ }^{383}$ "Experts say the hackers and the government are in a constant game of cat-andmouse, with the first constantly finding loopholes and the other moving just as quickly to close them."384 Technologies are constantly being developed to

373. Melinda Liu, China: Now Big Brother Is Talking to You, NEwswEEK INT'L, Oct. 17, 2005, available at http://www.msnbc.msn.com/id/ 9630976/site/newsweek/print/1/displaymode/1098/ [hereinafter Liu, Big Brother].

374. Id.

375. Id.; Administration of News, supra note 89, art. 19.

376. Liu, Big Brother, supra note 373; Administration of News, supra note 89, art. 19.

377. Liu, Big Brother, supra note 373.

378. Id.

379. Id.

380. Congressional-Executive Commission on China, Ministry of Public Security Reports Rise in Public Order Disturbances in http://www.cecc.gov/pages/virtualAcad/index.phpd?showsingle=37602 (last visited Oct. 4, 2006).

381. Id.

382. See generally Liu, Big Brother, supra note 373 (describing the anti-Japanese protests).

383. Feir, supra note 58 , at 384.

384. Q\&A: China's New Internet Restrictions, N.Y. TIMES, Sept. 29, 2005, available at http://www.nytimes.com/crf/international/slot1_092905.html. See also WONG, MATTER OF 
allow users to access information that has been blocked. ${ }^{385}$ Online activists provide information and services that assist citizens in countries with repressive governments to create blogs that are anonymous or less likely to be blocked. ${ }^{386}$ These are some of the reasons that "attempts to physically limit Internet access[] are merely a nuisance to determined users." 387 Therefore, the CCP must constantly update censorship techniques and regulations that prohibit circumventing state control in order to combat users who attempt to access controversial information and the activists that assist them. ${ }^{388}$

Circumvention technologies can route a user's request from inside a country that censors online content through an intermediary machine that is not subject to the same blocking. ${ }^{389}$ This intermediary retrieves the content that the user requested and sends the content back to the user. ${ }^{390}$ There are several forms of circumvention technologies that vary in complexity. ${ }^{391}$ Web-based circumvention is the easiest type of circumvention technology to use. ${ }^{392}$ These are public web pages that allow users to type in a URL that they want to visit, and the circumvention site will deliver the content. ${ }^{393}$ Most web-based circumvention sites are well-known and easily blocked by the government; if the user cannot access the circumvention site, then the user cannot use the service. $^{394}$

There are also private web-based circumventors, which require the installation of software but are more difficult for the government to discover and block. ${ }^{395}$ A private circumventor requires an entity in a non-censored location with sufficient technical expertise and available bandwidth to accommodate the users in the censored location. ${ }^{396}$

Another technique that users can employ to circumvent Party filtering is the use of proxy servers. ${ }^{397}$ A proxy server is a server positioned between a client and a server, acting as a buffer between them. ${ }^{398}$ "To use a proxy server,

TRUST, supra note 257, at 2.

385. See generally HANDBOOK FOR BLOGGERS, supra note 301. However, technologies to prevent circumvention techniques are also constantly developed; the sale of web filtering products reached $\$ 433$ million in 2004. Red Herring, The Business of Censorship (Oct. 31, 2005), http://www.redherring.com/Article.aspx?a=14405\&hed=The+Business+of+Censorship\#.

386. See, e.g., HANDBOOK FOR BLOGGERS, supra note 301, at 54; Electronic Frontier Foundation, How to Blog Safely, http://www.eff.org/Privacy/Anonymity/blog-anonymously.php (last visited Dec. 18, 2006).

387. Feir, supra note 58, at 384.

388. See generally Morais, supra note 172 (describing technology designed to circumvent the CCP's filtering techniques).

389. HANDBOOK FOR BLOGGERS, supra note 301, at 64.

390. Id.

391. Id.

392. Id. at 67.

393. Id.

394. Id. at 68.

395. Id. at 69.

396. Id.

397. Id. at 70.

398. Id. at 71. 
the end-user must configure the settings of their web browser with the IP address or hostname of the proxy server as well as the port number that the proxy server is running on." 399 Users can also find online lists of open IP addresses that can be used as proxies. ${ }^{400}$ "After users in the filtered locations configure their browsers to point through the proxy server[,] they can transparently surf the Internet." 401 Software proxy servers are more adaptable for use with websites that require cookies or authentication than web-based proxy servers are. ${ }^{402}$ Proxy software is growing in popularity as a method of circumvention in China. ${ }^{403}$ "Activists smuggle proxy software into China and pass it hand-to-hand on flash memory devices."

Another example of software designed to assist users in China is called DynaWeb, which was created by Chinese-American engineers in North Carolina. ${ }^{405}$ DynaWeb is similar to a proxy server that uses peer-to-peer connections to allow users to circumvent Internet control in China. ${ }^{406}$ It can be used by accessing links or through software called Freegate or DynaPass. ${ }^{407}$ More than ninety percent of the visitors that use DynaWeb are from China. ${ }^{408}$ This and other similar software is consistently used by an estimated 100,000 Chinese citizens to access information that is blocked by the Party. ${ }^{409}$

There are other worldwide organizations that challenge the CCP through technological or political means. ${ }^{410}$ The Epoch Times is an organization that

399. Id.

400. Id. at 73 .

401. Id. at 72 .

402. Id.

403. James Burke, "Tuidang" is Chinese for "Withdrawal from the Party" (Oct. 18, 2005), available at http://www.theepochtimes.com/news/5-10-18/33463.html.

404. Forney, supra note 156.

405. Chen, supra note 226, at 243.

406. Dynamic Internet Technology, http://www.dit-inc.us/dynaweb.php (last visited Dec. 19, 2006). Peer-to-peer, also called P2P, connections are "computer systems which are connected to each other over the Internet. Files can be shared directly between systems on the network without the need of a central server." TechTerms.org, P2P (Peer to Peer) Definition, http://www.techterms.org/definition/p2p (last visited Nov. 9, 2006).

407. Dynamic Internet Technology, supra note 406.

408. Id.

409. Reporters Without Borders, Google.com Blocked as Vice Tightens on Chinese Users (June 6, 2006), http://www.rsf.org/article.php3?id_article=17936. A software engineer reported that in June 2006, jamming of the programs had reached "unprecedented level[s]," which he attributed to the Party "deploying considerable hardware and software resources to achieve." Id. Reporters Without Borders noted that the jamming subsided a few days later and speculated that the CCP had "stepped up" online censorship during the days before and after the anniversary of Tiananmen Square. Id.

410. See, e.g., Amnesty International, http://www.amnesty.org (last visited Dec. 19, 2006); Electronic Frontier Foundation, http://www.eff.org (last visited Dec. 19, 2006); Human Rights in China, http://hrichina.org (last visited Dec. 19, 2006); OpenNetInitiative, http://www.openneteinitiative.net (last visited Dec. 19, 2006); Radio-Free Asia, http://rfa.org (last visited Dec. 19, 2006); Reporters Without Borders, http://rsf.org (last visited Dec. 19, 2006); Voice of America, http://www.voanews.com (last visited Dec. 19, 2006). 
created and published a book entitled, "Nine Commentaries on the Communist Party." 411 "Nine Commentaries" traces the history and tyranny of the CCP for Chinese citizens who are, because of censorship, probably unaware of many of the historical events surrounding the establishment and control of the CCP. ${ }^{4 / 2}$ The organization distributes the book, emails it as a text file, and makes the information accessible in other media formats. ${ }^{413}$ Users are encouraged to copy and disseminate the information. ${ }^{414}$ More than fifteen million people have renounced the Party on this organization's website. ${ }^{415}$ Most of the Chinese citizens who renounce the CCP achieved this by using DynaWeb to reach The Epoch Time's website. ${ }^{416}$

The United States government has funded organizations such as Voice of America and Radio Free Asia, which are groups that provide news information to China and other countries through radio and satellite broadcasts and websites. $^{417}$ In 2003, U.S. Representative Christopher Cox introduced legislation entitled the Global Internet Freedom Act (Act), which would combat censorship tactics in China and other repressive countries. ${ }^{418}$ The Act was reintroduced in the House of Representatives in $2005^{419}$ and $2006{ }^{420}$

The Act would create an office of Global Internet Freedom, which would operate to "develop and implement a comprehensive global strategy to combat state-sponsored and state-directed Internet jamming by repressive foreign

411. The Epoch Times, Denouncing the Chinese Communist Party, http://declaration.epochtimes.com/ (last visited Dec. 19, 2006). See also The Epoch Times, Nine Commentaries on the Chinese Communist Party, http://www.ninecommentaries.com (last visited Dec. 19, 2006) [hereinafter Nine Commentaries].

412. Id.

413. Dynamic Internet Technology, Report on Chinese People Renouncing the Chinese Communist Party Via InTernet Circumvention Technologies (2005), http://www.dit-inc.us/report/9p200505/9pExecutiveSummary.html [hereinafter REPORT ON CHINESE PEOPLE]. See also Morais, supra note 172. The book has been promoted with 100 million emails, 12 million traditional mails, 10 million faxes, and 50 million phone calls. Id.

414. REPORT ON CHINESE PEOPLE, supra note 413.

415. Nine Commentaries, supra note 411. It appears that the majority of the withdrawals are from Chinese citizens, but citizens of other countries have signed the declaration as well. Denouncing the Chinese Communist Party, supra note 411. In March 2006, there were more than five hundred resignations from the Party on the English-language page of the website, which included signatures from the United States and Canada. Id. In contrast, there were more than 23,000 pages of names and resignations on the Chinese-language website. The Epoch Times, Renouncing the Chinese Party, http://tuidang.dajiyuan.com (last visited Dec. 19, 2006).

416. REPORT ON CHINESE PEOPLE, supra note 413.

417. See Chen, supra note 226 , at 233-34. The broadcasts are regularly "jammed" by the $\mathrm{CCP}$ by playing diffuse music or static at the frequencies of known broadcasts. MANOSIJ GUHA, TIBET: MAKING WAVES ATOP THE WORLD 56-57 (n.d.), http://www.passband.com/pdf_files/tibet.pdf.

418. Chen, supra note 226, at 229; Global Internet Freedom Act, H.R. 48, 108th Cong. (2003). To see the reactions of a few Chinese bloggers to the Act, see RConversation, GOFA:

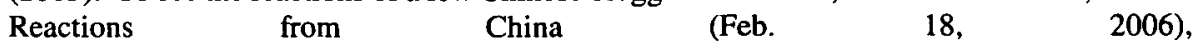
http://rconversation.blogs.com/rconversation/2006/02/gofa_bloggers_r.html.

419. Global Internet Freedom Act, H.R. 2216, 109th Cong. (2005).

420. Global Internet Freedom Act, H.R. 4741 109th Cong. (2006). 
governments . ..."421 The Act would allocate funds for anti-jamming technology use and development, and the expertise of the private sector would be utilized to develop and implement the technologies. ${ }^{422}$ Although the Act seemed to be slow to gain political attention, U.S. Secretary of State Condoleezza Rice created a Global Internet Freedom Task Force in February $2006 .{ }^{423}$ Yahoo!, Google, and other U.S. Internet companies were asked to attend congressional briefings on their respective roles in aiding the CCP in censorship. ${ }^{424}$ Due to the actions of these U.S. companies in 2005 and 2006, the Act received much more attention in 2006 than in previous years. ${ }^{425}$

Even as "the rest of the world is doing its best to make sure the Chinese government fails, ${ }^{, 426}$ the CCP does not sit idly by as organizations and governments develop circumventing technologies. ${ }^{427}$ The Party blocks the names of circumventing systems and Internet freedom organizations in order to prevent citizens from learning about their existence or operation. ${ }^{428}$ Even though the Party is unable to prevent all Chinese citizens from accessing illegal information, "[i]t's important to remember that success in filtering doesn't require total control; it just requires altering the average online experience of the average user," which the CCP has become quite adept at doing. ${ }^{429}$ Due to the regulations, the "casual user" is unlikely to stumble upon controversial information, even though those citizens who are technically sophisticated can find a way around the filters. ${ }^{430}$ "[T] he government accepts the leakage as long as it can squelch the loudest voices." ${ }^{, 431}$

421. H.R. $4741 \S 4($ a).

422. H.R. $2216 \S 3(5)$. However, several private U.S. corporations are complicit in helping the Party censor the Internet. See supra notes 166, 200, 231, 250, 255 and accompanying text. For an analysis of the viability of the Global Internet Freedom Act, see Chen, supra note 226.

423. U.S. Department of State, Secretary of State Establishes New Global Internet Freedom Task Force (Feb. 14, 2006), http://www.state.gov/r/pa/prs/ps/2006/61156.htm.

424. Id.

425. See Assoc. Press, Lawmakers Blast Internet Firms over China (Feb. 1, 2006), http://msnbc.msn.com/id/11134689. See also Josette S. Shiner, Remarks on Global Internet Freedom, (Feb. 20, 2006), available at http://www.state.gov/e/eb/rls/rm/2006/61182.htm. Legislation was also being drafted in 2006 that would prevent companies such as Google and Yahoo! from providing services in repressive countries such as China. Id.

426. Mizuki, supra note 258.

427. See id.

428. See id. The author puts asterisks in the middle of the names of software that allows access to foreign-based web sites such as "Dynapass," "Freegate," and "Ultrasurf," noting that the asterisks "were added after a reader in China wrote to tell me that this post was being blocked at precisely this point." Id.

429. Radio Free Asia, China's Internet Controls Raise Tough Questions (Sept. 14, 2005), http://www.rfa.org/english/news/politics/2005/09/14/china_internet/.

430. Faris, supra note 142.

431. Id. 


\section{CONCLUSION}

Although the CCP is highly concerned with accentuating the positive effects of e-commerce in China and reducing the negative effects of citizens' access to political dissent, studies have shown that the average Internet user in China does not often access the Internet for either of these objectives. ${ }^{432}$ The typical Chinese Internet user is less than thirty years old, single, and primarily uses the Internet for accessing entertainment news, playing online games, instant messaging, and downloading music. ${ }^{433}$ It is unclear whether these web trends are a result of the strict Internet regulations or if the Chinese culture merely views the Internet in a different manner than Western citizens, who primarily use the Internet for information gathering or for efficiency reasons such as buying tickets or paying bills. ${ }^{434}$

Some commentators believe that " $[\mathrm{m}]$ any Chinese Internet users barely notice the restrictions; they're grateful to have expanded sources of information and entertainment. Millions of Web sites exist in Chinese, satisfying the estimated 80 percent of users who stick only to regulated Chinese-language sites and rarely venture into the freewheeling global internet. ${ }^{, 435}$ Others believe that the majority of Chinese citizens are interested in political events but their interest is suppressed because they do not have access to that type of information. ${ }^{436}$ Still others believe that the Western media places far too much emphasis on censorship and ignores the expanded freedom of expression that the Internet allows in China. ${ }^{437}$

The Internet is still a relatively new medium, particularly in China where only $8.5 \%$ of the population uses the Internet. ${ }^{438}$ The CCP has developed stringent and fairly effective mechanisms of content control by regulation through legal methods, technological methods, and access methods. These methods of regulation have proven to be sustainable for the last decade. Although the methods are not infallible, the government has created a level of intimidation that deters many users from accessing controversial information. By continually updating the laws to reflect changes in technology and by implementing new technological measures to enforce the laws, the $\mathrm{CCP}$ will continue to control the Internet successfully to the extent that a casual user will not be able to access forbidden information.

However, due to rapid changes in technology, efforts by hackers and activists, and expanding access to the remainder of China's population, it is likely that the methods of control by the CCP will not remain feasible

432. Gonsalves, supra note 257.

433. Id.; Johnson, supra note 162; WONG, MATTER OF TRUST, supra note 257, at 2.

434. Deborah Fallows, Pew Internet: Women and Men Online, http://www.pewinternet.org/PPF/r/171/report_display.asp (last visited Dec. 19, 2006).

435. Johnson, supra note 162.

436. Id.

437. Lemon, China Finds Freedom, supra note 178.

438. 111 Million, supra note 2. 
indefinitely for users who seek out forbidden information. Circumvention efforts will continue to keep pace with censorship efforts. The number of Chinese-language websites that the Party will need to oversee will also continue to increase dramatically. ${ }^{439}$

Although China may not be transforming into the free democracy that so many people predicted the Internet would create, sustaining such a highly regulated system of control will become increasingly difficult for the Party when the Internet population reaches, for instance, 500 million users. Nevertheless, the CCP will not give up Internet content control easily. As one city's public security bureau monitoring department director stated:

It is different from what the outside world understands. We have been trying to seek a balance between preserving privacy and protecting order and safety. As far as we are concerned, the Internet is a battleground and the keyboard is the handgun. We are going where no one has gone before. ${ }^{440}$

439. The ".cn" top-level domain name server already receives more than 600 million domain name analysis requests every day. China Tech News, New Chinese Top Node Put Into Operation (June 15, 2006) (on file with author).

440. Fourteen Departments, supra note 13. 